\title{
Seletividade da esfera pública e esferas públicas subalternas: disputas e possibilidades na modernização brasileira
}

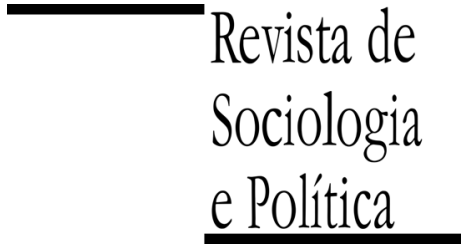

DOI 10.1590/1678-987315235307

\section{Fernando Perlatto}

\begin{abstract}
Resumo
O artigo analisa o processo de constituição da esfera pública no Brasil. Sugere-se a hipótese segundo a qual, pelo menos desde o século XIX, constituíram-se uma esfera pública seletiva e esferas públicas subalternas. Para sustentar o argumento proposto, procura-se, por um lado, estabelecer um diálogo com a literatura internacional dedicada à reflexão em torno do conceito de esfera pública - em especial com as formulações realizadas por e a partir de Jürgen Habermas -, com o intuito de explorar as transformações que essa categoria passou no decorrer dos anos, dando ênfase especial ao conceito de "subaltern counterpublics", proposto por Nancy Fraser. Por outro lado, busca-se, com apoio de estudos historiográficos realizados no decorrer das últimas décadas sobre a sociedade brasileira dos séculos XIX e XX, construir uma formulação teórica acerca do processo de configuração da esfera pública no Brasil. Além de problematizar as teorias que sustentam a inexistência de uma esfera pública no país, ou que concebem sua constituição somente a partir do final do século XX, procura-se apontar não somente para a necessidade de um olhar histórico mais acurado para a compreensão das esferas públicas "seletiva" e "subalternas", mas um movimento analítico no sentido de perceber outras formas de associativismo como legítimas que não se prendam ao paradigma organizacional do mundo europeu ou norte-americano. O artigo contribui tanto para uma melhor compreensão histórica do processo de configuração da esfera pública no Brasil quanto para um entendimento mais bem compreendido da dinâmica de organização e mobilização das "esferas públicas subalternas", chamando a atenção para suas potencialidades ao aprofundamento da democratização do país.
\end{abstract}

PALAVRAS-CHAVE: esfera pública; Habermas; subalternos; modernidade; democracia.

Recebido em 17 de Maio de 2013. Aprovado em 30 de Julho de 2014.

\section{Introdução ${ }^{1}$}

${ }^{1}$ Agradeço os pareceristas anônimos da Revista de Sociologia e Política por seus comentários. Agradeço também a Luiz Werneck Vianna e a Frédéric

Vandenberghe pela leitura crítica e fraterna, que me foram de inestimável valia
Já é bem conhecida pelas nossas ciências sociais a capacidade exemplar das elites brasileiras, ao longo dos anos, de mudar para conservar. Os pactos por cima, que procuraram excluir de todas as formas o povo das decisões significativas da nação, não se configuraram como pequenos ínterins na nossa trajetória, mas se constituíram como condição sine qua non capaz de assegurar o andamento conservador da modernização no Brasil. O processo modernizador por aqui, ao contrário do ocorrido em outros paradigmas clássicos, não se configurou como uma ruptura com o "atraso", mas como um longo processo contínuo, marcado pelo entrelaçamento entre o "arcaico" e o "moderno", logrando constituir uma ordem social altamente desigual, na qual o elemento da continuidade tendeu a prevalecer sobre o da transformação. Durante muitos anos, a razão dualista - que opunha pares de conceito como arcaico-moderno, rural-urbano, agrário-industrial, sociedade fechada-sociedade aberta, sociedade estagnada-sociedade dinâmica, sociedade tradicional-sociedade de massas, feudalismo-capitalismo - foi considerada como a chave explicativa da realidade nacional, sendo mobilizada por setores importantes da intelectualidade brasileira e latino-americana. A partir dos anos 1960 essa perspectiva começou a sofrer diversas críticas de estudiosos que apontavam para as intrínsecas relações 
existentes entre o moderno e o atraso na constituição do capitalismo no país. Respeitadas as singularidades e particularidades, essa nova forma de compreensão da modernização brasileira esteve presente em diversos autores, como Fernando Henrique Cardoso, Francisco de Oliveira, Luciano Martins, Florestan Fernandes e Luiz Werneck Vianna.

Visto desse prisma, portanto, nossa modernização já se processou, ainda que conservando elementos arcaicos, e não nos diferenciamos de outras nações pelo fato de não termos ainda atingido a modernidade pela nossa tão propalada herança ibérica, que nos manteria presos ao mundo da tradição. Ao criticar a nossa "sociologia da inautenticidade", Jessé Souza, dialogando criticamente com a obra de Gilberto Freyre, demonstra que as instituições fundamentais da modernidade, quais sejam o Estado e mercado, associadas à difusão dos valores "ocidentais" individualistas, estariam presentes em nosso território desde o século XIX, sobretudo a partir da Abertura dos Portos e da chegada da família real no Brasil, em 1808. Porém, como destaca Souza, embora essa modernização tenha sido efetiva e não superficial, os mecanismos de integração social e política permaneceram profundamente hierarquizados ao longo dos anos, promovendo uma "modernização seletiva” (Souza 2000).

Partindo das sugestões levantadas por Souza em relação ao Estado e ao mercado, pretendemos demonstrar que a terceira instituição da modernidade qual seja, a esfera pública - também está presente no Brasil desde o século XIX. Conforme bem observado por Sérgio Costa, durante muitos anos perdurou no país a ideia da inexistência de um espaço público entre nós, na medida em que se acreditava que "a esfera privada apresentava-se de tal forma ampliada que a lógica das relações pessoais e patrimonialistas seria ‘contrabandeada' para o plano público, condicionando os relacionamentos nessa órbita" (Costa 2002, p. 30). A partir das décadas de 1980 e 1990, contudo, diversos estudos contribuíram para consolidar a convicção da existência no país de um espaço público (Avritzer 2002; Costa 2002; Avritzer \& Costa 2003). Ao criticarem as teorias de transição da democracia focadas em dimensões institucionais e no papel desempenhado pelas elites, essas pesquisas tiveram o mérito de chamar a atenção para a importância da participação dos novos atores sociais emergentes no contexto da redemocratização do país (movimentos sociais, associações de vizinhos, ONGs etc.), trazendo o conceito de "esfera pública" para o centro da reflexão analítica e normativa sobre a democracia.

Não obstante a importância desses trabalhos, o foco dos mesmos se concentrou nas décadas de 1970, 1980 e 1990, como se a esfera pública apenas tivesse se configurado no país no contexto do fim da ditadura militar, quando "novas formas de associativismo voluntário e novas práticas públicas renovaram o repertório de práticas políticas, fomentando, assim, novas formas de engajamento cívico" (Wampler \& Avritzer 2004, p. 212). O processo de construção da nação teria sido marcado, segundo se desprende desses estudos, pela desorganização cívica e desmobilização da sociedade civil, como decorrência da dominância de práticas autoritárias e clientelistas. Dessa forma, ainda que destacando a importância desses trabalhos para problematizar as formulações que sustentam a inexistência de uma esfera pública no país, é preciso reconhecer a insuficiência dos mesmos no sentido de compreender como se processou historicamente a construção da esfera pública no país.

A partir de um diálogo com a historiografia brasileira que tem se debruçado para compreender aspectos dos séculos XIX e XX, esse artigo defende a hipótese de que a esfera pública, ao lado do Estado e mercado, configurou-se no Brasil desde o século XIX, ainda que sua construção tenha sido marcada pela seletividade, tanto no que tange aos personagens capazes de nela operar, quanto em relação aos temas a serem debatidos em seu âmbito. Não obstante a 
construção dessa esfera pública seletiva, apontaremos ao fato de que, pari passu, ocorreu a formação de esferas públicas subalternas, constituídas por diferentes espaços de sociabilidade nos quais os segmentos subalternos buscaram se organizar. Nesse sentido, é importante ressaltar desde já que, a despeito de separarmos analiticamente a esfera pública seletiva e as esferas públicas subalternas, não se pretende sugerir que elas se configuraram de maneira isolada. Pelo contrário. Parte-se do pressuposto de que essas esferas se relacionam permanentemente, quer de forma dialógica, quer de maneira conflituosa. Não obstante se reconheça a existência de uma "circularidade cultural" entre essas esferas - para utilizar a formulação conceitual de Ginzburg (1998), em diálogo com Mikhail Bakhtin -, com cada qual filtrando determinados elementos da outra, a partir de seus próprios valores e condições de vida, é preciso reconhecer que as relações comunicacionais entre elas se deram, historicamente, de maneira desigual, com a busca constante da primeira em construir um discurso hegemônico sobre a segunda. Além disso, como bem percebido por Nancy Fraser, em sociedades estratificadas, as relações entre os diferentes públicos pertencentes a estas esferas tendem a ser mais de contestação do que de propriamente de deliberação (Fraser 1992, p. 125).

Baseado nessa discussão acerca da institucionalização seletiva dos processos deliberativos na história brasileira, demonstrar-se-á, à guisa de conclusão, a necessidade da ampliação da democratização da esfera pública, mediante não apenas a institucionalização de procedimentos democráticos capazes de dar vazão a argumentos "racionais", mas de mecanismos que a tornem mais porosa aos valores, demandas, reivindicações e manifestações dos setores subalternos. A ideia subjacente a essa perspectiva é a da necessidade da ampliação de canais que permitam que as potencialidades do mundo da vida aqui existente, historicamente manifestadas principalmente por meio de performances e "discursos ocultos", possam se manifestar em uma esfera pública renovada e democrática.

\section{Uma breve introdução sobre o conceito de esfera pública e seus críticos}

2 Além das obras de Habermas (1984; 1992; 1997; 2002; 2012), tem-se como referência, quanto a esse tópico, as análises de Avritzer (1996), Calhoun (1992; 2010), Costa (2002) e Maia (2007a).
Não se tem como objetivo fazer uma ampla discussão sobre a obra habermasiana, considerada por muitos, com razão, como "o momento mais alto de racionalização do mundo existente", sobretudo por perpassar praticamente todos os campos disciplinares das humanidades e colocar-se em interlocução com quase todas as tradições importantes da reflexão contemporânea, oferecendo uma perspectiva crítica à modernidade sem, contudo, abdicar das suas potencialidades teóricas e práticas (Eisenberg 2003a, pp. 24-26). Pretende-se, nesse sentido, apenas introduzir a discussão de Habermas sobre a "esfera pública" com o intuito de destacar algumas críticas pelas quais esse conceito passou nos últimos anos para, posteriormente, discutir como se deu o processo da sua constituição no Brasil².

A primeira formulação sistemática em torno do conceito de "esfera pública" foi realizada por Habermas em sua tese de livre-docência, Mudança estrutural da esfera pública, publicada em 1962. Nessa obra, Habermas procurou descrever o processo histórico de configuração de um novo espaço a partir do século XVIII, principalmente na Inglaterra, França e Alemanha, situado entre a sociedade e o Estado, que tinha como principal característica o debate livre e racional entre os cidadãos sobre questões públicas. A constituição dessa esfera esteve diretamente associada à ascensão da burguesia, bem como ao crescimento das cidades, à proliferação dos cafés e dos salões e, sobretudo, ao novo papel adquirido pela imprensa, que passou a se configurar como um "fórum" apartado das instâncias estatais, no qual se debatiam questões públicas e se constituíam opiniões críticas topicamente definidas, capazes de problematizar publicamente a legitimidade das ações do Estado. 
A esfera pública se configurou, segundo Habermas, como uma nova fonte de legitimidade do poder, que tinha como característica principal a discussão livre e racional entre os cidadãos. Nesse espaço, as opiniões passaram a ser legitimadas pela força dos melhores argumentos racionais mobilizados no debate público, que deveriam ser considerados e valorizados independentemente de fatores como poder, riqueza ou status social. De acordo com Habermas, ao longo dos anos, a esfera pública sofreu uma série de mudanças estruturais, passando a se constituir, no século XIX, como um espaço de pressão, como decorrência do próprio processo de democratização e da ampliação do público que passou a exigir a consideração de seus interesses no sistema político. Já no século XX, a esfera pública teria passado por um processo gradativo de degeneração, como decorrência da obliteração da divisão entre as esferas privada e pública, quer pela privatização de espaços outrora pertencentes ao domínio público, quer pela intervenção cada vez mais ampliada do Estado no domínio privado, que teriam conduzido à transformação do "cidadão" em "cliente" ou "consumidor de serviços".

Conforme destacado por diferentes autores, nos trabalhos posteriores de Habermas - sobretudo em A teoria do agir comunicativo e Direito e democracia -, a esfera pública deixa gradativamente de se referir a uma instituição histórica específica ou a suportes institucionais particulares, passando a se vincular à capacidade a-histórica do homem para a comunicação humana (Calhoun 1992; Lavalle 2002). Ao pensar a esfera pública mais associada aos fluxos comunicativos espontâneos que emergem na sociedade, a partir do debate e da discussão livre sobre questões de interesse comum entre os cidadãos considerados iguais, política e moralmente, Habermas procurou inserir essa categoria no núcleo de sua teoria "procedimentalista" da democracia, apontando-a como uma arena discursiva do agir orientado para o entendimento, na qual os valores democráticos se formariam e se reproduziam a partir de redes de comunicação de conteúdos e tomadas de posição (Habermas 1992; 2012).

O que interessa reter dessa discussão é o fato de a concepção de "esfera pública burguesa", desenvolvida por Habermas em Mudança estrutural da esfera pública, ter gerado diversas críticas no decorrer dos anos, que conduziram a uma reformulação conceitual da categoria, inclusive nas obras posteriores do autor. Se alguns trabalhos enfatizaram a ausência de uma discussão mais detalhada de aspectos culturais e identitários na obra de Habermas de 1962 (Baker 1992; Elley 1992), outros procuraram destacar a pouca importância conferida à religião na configuração da esfera pública (Zaret 1992). Alguns estudiosos buscaram problematizar o enfoque pessimista de Habermas sobre o século XX, focado no processo de degeneração da esfera pública, com o intuito de demonstrar o quanto sua análise sobrevalorizava o quadro de homogeneização da mídia e as consequências de sua massificação e alienação - fazendo eco aos diagnósticos pessimistas da Dialética do Esclarecimento - desconsiderando a emergência de novos segmentos sociais e a possibilidade de que fluxos comunicativos originários do mundo da vida pudessem ser mobilizados no debate público, por meio da pressão de associações voluntárias desvinculadas do mercado e do Estado (Calhoun 1992; Avritzer 2000; Costa 2002).

Não obstante a importância dessas objeções a Mudança estrutural da esfera pública, interessa-nos enfatizar outra ordem de críticas, que contribuíram sobremaneira para repensar a temática da esfera pública a partir de novas perspectivas teóricas. De modo geral, pode-se dizer que essas críticas procuraram problematizar a formulação de Habermas sobre a esfera pública, chamando a atenção para a desconsideração, em sua obra, quanto à existência de outras esferas públicas na sociedade, constituídas por segmentos como os operários e as mulheres que, não obstante excluídos da esfera pública burguesa, formularam discursos e participaram de diferentes maneiras dos debates sobre 
questões públicas. Se Negt e Kluge (1993) tiveram o mérito, em 1972, de realizar uma primeira crítica mais ampla à formulação habermasiana, no livro The Public Sphere and Experience. Toward an analysis of the bourgeois and proletarian public sphere, demonstrando como uma esfera pública proletária atuava em paralelo à esfera burguesa, foi Nancy Fraser quem melhor sistematizou essas objeções, ao desenvolver o conceito de "subaltern counterpublics" (Fraser 1992).

Não obstante reconhecesse a importância da elaboração de Habermas em torno do conceito de "esfera pública", Fraser o criticava por idealizá-la, ao não perceber como essa esfera se constituíra pela exclusão de diversos segmentos da sociedade, como as mulheres e os operários. Frente a esse quadro de exclusão, os subaltern counterpublics constituíram arenas discursivas paralelas por meio das quais criaram e circularam discursos contestadores, de sorte a formularem interpretações e definirem suas identidades, interesses e necessidades (idem). Posteriormente, alguns trabalhos exploraram essas ideias dos counterpublics, quer teoricamente (Warner 2002; Calhoun 2012), quer empiricamente (Asen \& Brower 2001; Squires 2002), ao passo que outros autores aproximarão essa categoria de outros conceitos como o de new publics (Cohen \& Arato 1992) relacionado à emergência de novos públicos e de formas críticas de comunicação, vinculados aos movimentos sociais, que se constituem paralelamente ao crescimento da grande mídia - e diasporic publics (Gilroy 2001) - que diz respeito ao desenvolvimento, junto com a diáspora africana, de uma contracultura fora da órbita da política formal, que se valeu da performance, da dança e da música como forma de manifestação (Avritzer \& Costa 2004, pp. 710-714). Não obstante, importa destacar que apesar das críticas realizadas a Habermas pela desatenção a outras esferas púbicas existentes na sociedade, ele já destacava no "Prefácio" da Mudança estrutural da esfera pública que concentraria sua análise no modelo liberal da esfera pública burguesa. Dessa forma, ele não se debruçaria sobre a sua "variante plebeia", que reuniria a "plebe ignara", e que teria emergido no período da Revolução Francesa, permanecendo atuante no movimento cartista e nas tradições anarquistas do movimento operário (Habermas 1984, pp. 10-11). A despeito dessa ressalva, Habermas admitirá posteriormente que o enfoque por ele privilegiado obstou uma percepção mais bem formulada da dinâmica interna da cultura plebeia e de seu potencial para a dinamização do debate público (Habermas 1992).

Seguindo as sugestões levantadas por Habermas sobre as mudanças estruturais da esfera pública e por seus variados críticos, em especial Nancy Fraser e seu conceito de subaltern counterpublics, a construção da esfera pública no Brasil será analisada buscando-se demonstrar como ela se configurou de maneira seletiva, tanto em relação aos personagens do mundo subalterno, quanto aos interesses que vinham "de baixo" e aos temas que poderiam colocar a ordem desigual aqui construída em cheque. Em seguida, será destacado o desenvolvimento daquilo que chamaremos de esferas públicas subalternas, por meio das quais os setores populares procuraram estabelecer arenas discursivas alternativas àquelas constituídas pelos segmentos elitistas.

O conceito de "esferas públicas subalternas" se inspira na categoria de "subaltern counterpublics" de Nancy Fraser, mas dele se diferencia por não colocar tanta ênfase na ideia segundo a qual os públicos subalternos seriam necessariamente contrários à esfera pública seletiva. Ainda que em alguns momentos da história brasileira eles tenham assumido essa perspectiva de contestação, seria equivocado defini-los apenas a partir da sua oposição à esfera pública seletiva, o que equivaleria tanto a reduzir a importância da própria dinâmica interna dessas esferas públicas subalternas quanto as complexas relações existentes entre as diferentes esferas públicas. 


\section{Seletividade da esfera pública brasileira}

${ }^{3}$ Os trabalhos de Arjomand (2001) e a coletânea organizada por Hoexter, Eisenstadt e Levtzion (2002), respectivamente sobre a Índia e as sociedades mulçumanas, são exemplos de investigações sobre o processo de configuração da esfera pública em contextos "periféricos".
De acordo com Warner (2002), a ideia de público se configura como uma espécie de "ficção prática" presente no imaginário social de diferentes sociedades. Na maior parte das vezes, noções como "público", "esfera pública" e subaltern counterpublics são tomadas como se trouxessem em seu bojo um significado explicativo universal, independente dos contextos ao quais são aplicadas. Porém, como destacado pelo autor, as experiências nacionais possuiriam um papel importante para a investigação dessas categorias, na medida em que os solos nos quais elas decantam recolocam novos desafios para a própria investigação teórica. Nesse sentido, pensar a dimensão do público implica atentar para um imperativo "descentramento" da teoria social que leve em conta as diversas formas pelas quais categorias sociológicas produzidas em determinados contextos são interpretadas e mobilizadas em outras realidades (Connell 2007). Refletir, portanto, sobre o processo de configuração da "esfera pública" em países "periféricos" ou "semiperiféricos" como o Brasil contribui sobremaneira para esse processo de "descentramento", possibilitando o diálogo entre diferentes experiências de modernidade, sem que se conceba a priori a superioridade de alguma delas sobre as demais, de modo a pensar de maneira mais ampliada o próprio conceito de esfera pública ${ }^{3}$.

A construção de uma sociedade altamente excludente como a brasileira, marcada por altos índices de analfabetismo e pelo desprezo frente ao trabalho manual, tido como "coisa de escravo", desde a Independência, permitiu a edificação da noção de que apenas alguns seletos seriam aptos a operar na esfera pública, organizando o debate público e instituindo o campo semântico em que ele se deu, selecionando temas e constituindo interlocutores legítimos. Essa forma de modernização, marcada pelo afastamento, quando não a exclusão, da maioria da população dos espaços de discussão pública e de deliberação, conduziu à conformação de uma esfera pública seletiva, a partir da qual setores dominantes formularam ideias e percepções que decantaram com enorme força por toda a sociedade. Ao sustentar-se a noção da seletividade da esfera pública no Brasil, não se pretende dizer que as esferas públicas constituídas em outros países, em especial na Europa e nos Estados Unidos, não foram também seletivas. Pelo contrário. Diversos estudos têm procurado apontar justamente para o fato de que as esferas públicas nesses contextos foram marcadas pela exclusão, na medida em que apenas aos homens burgueses era facultada a participação, resultando, consequentemente, na exclusão de diversos outros segmentos da sociedade (Fraser 1992; Ryan 1992; Calhoun 2012). Contudo, não resta dúvida de que em sociedades estratificadas como a brasileira, caracterizadas pela escravidão e por altos índices de analfabetismo, essa seletividade ganhou novos contornos, configurando-se de forma mais significativa e sistemática. Desde 1808, quando ocorre a chegada da família real, trazendo em seu bojo uma série de transformações políticas, sociais, econômicas e culturais, verificar-se-ão os primeiros indícios da construção de uma esfera pública no Brasil, ainda que pouco permeável tanto aos setores subalternos e aos seus interesses, quanto aos temas capazes de introduzir o novo nesse mundo, pondo em questão o status quo.

Junto com as mudanças desencadeadas a partir da Abertura dos Portos às Nações Amigas, em 1808, a chegada da família real ao Brasil, além de promover a criação de instituições culturais como a Biblioteca Real, a Imprensa Régia, o Jardim Botânico, a Academia de Belas Artes, além de teatros e museus, estimulou o desencadeamento de uma série de transformações, em todos os aspectos da vida e dos costumes, criando um ambiente favorável para reuniões, encontros e discussões públicas. Dessa forma, corroborando a análise feita por Antonio Candido, é possível destacar que a vinda da Corte para o Brasil marcou 
definitivamente o começo da nossa "época das luzes", haja vista que foi a partir de então que o país viu surgir os primeiros públicos consumidores regulares de arte e literatura, dando início a uma verdadeira, ainda que incipiente, "vida intelectual" (Candido 1971).

Segundo José Murilo de Carvalho, até o início do Segundo Reinado (1840), o debate político estava restrito a espaços escassos, concentrando-se principalmente na tribuna do Parlamento e na imprensa (Carvalho 2007). A exceção foram os anos da Independência, em especial após a após a Revolta Liberal do Porto, em 1820, e o período da Regência (1831-1840), quando jornais, associações e clubes políticos se organizaram, sobretudo na capital do Império. Conforme destacado pela historiografia, no decorrer desses anos, o processo de aparecimento dos jornais e de diferentes espaços de sociabilidade, como associações e clubes, favoreceu a formação de uma opinião pública no país que, ultrapassando os limites do julgamento privado, passou a influir o debate público, colocando em questão a legitimidade discursiva do Estado. Os momentos marcados por maior agitação, no decorrer do período imperial, como os que se seguiram à Independência e à Regência, foram aqueles nos quais a imprensa foi mais mobilizada, com a proliferação de espaços abertos ao debate público (Basile 2000; Lustosa 2000; Neves 2003; Morel 2005). Além disso, transformações nas próprias cidades, em especial na capital federal - como a disseminação de cafés, confeitarias e restaurantes - criarão ambiente favorável para o encontro das pessoas em locais públicos (Alencastro 1997, p. 85).

No decorrer do século XIX, as associações científicas, culturais e literárias com especial destaque para a Sociedade Auxiliadora da Indústria Nacional, a Academia Imperial de Medicina, a Sociedade de Geografia, o Clube de Engenharia, o Instituto Histórico e Geográfico Brasileiro e o Instituto dos Advogados Brasileiros - também se configuraram como espaços de animação intelectual e debate sobre questões públicas (Rezende de Carvalho 2007, p. 19). Conforme destacado por Luiz Felipe de Alencastro:

"Num contexto em que a política parlamentar e os debates importantes só tomavam corpo e expressão verdadeiramente nacionais nas estreitas camadas da população escolarizada, os jornais, panfletos e revistas desempenhavam um papel decisivo. $\mathrm{Na}$ ausência de um verdadeiro mercado editorial de livros e de uma massa de leitores formados pelo ensino acadêmico e a frequentação de bibliotecas públicas, os periódicos apareciam como veículos quase exclusivos da difusão de ideias" (Alencastro 2001, p. 116).

Embora a liberdade da imprensa só tenha sido implementada em 1821, desde 1820, após a revolta liberal do Porto, houve uma intensificação do debate político principalmente mediante a publicação de folhetos e jornais. Esses materiais foram mobilizados pelos políticos e intelectuais do Império, constituindo-se nos principais veículos de debates públicos (Carvalho 2006, p. 139). A imprensa da Corte contava com três grandes jornais - Correio Mercantil, Diário do Rio de Janeiro e Jornal do Commercio. Ao lado da publicação dessas folhas, no decorrer do período imperial foram se multiplicando os panfletos e livros, que também formavam um campo de debate entre a elite alfabetizada naquele contexto (Barbosa 2007). Embora a conformação dessas esferas de reunião e discussão se desse com maior força na Corte, elas não se restringiam a essa geografia. Como exemplo, basta observar o que ocorria na província de Minas Gerais, onde a primeira metade do século XIX testemunhou o aparecimento de novas formas de convívio, sociabilidade e reunião no espaço público (Barata 2009).

Nem é preciso dizer que os debates alçados principalmente pela elite intelectual e política do Império a essa restrita esfera pública alcançavam um 
${ }^{4}$ Se porventura pudesse haver existido um debate sobre a democratização das terras, a Lei de Terras de 1850 pôs por água abaixo essas possibilidades, ao consagrar o latifúndio e impedir a efetiva realização de uma reforma agrária no país (Costa 1982). Quanto ao tema da escravidão, houve uma "produção do silêncio" sobre a raça no decorrer do Império por parte da elite intelectual, inclusive como um requisito para se alcançar o ideal de homogeneidade da nação (Chalhoub 2006). número muito reduzido da população. À escassez de espaços democráticos para que os setores subalternos deles participassem se somava um número elevadíssimo de analfabetos, que se não inviabilizava, ao menos reduzia significativamente a possibilidade de interação autônoma por parte dos segmentos populares. De acordo com censo realizado em 1872 e divulgado quatro anos depois, na população livre, apenas $23,43 \%$ dos homens e $13,43 \%$ das mulheres sabiam ler e escrever. Caso os escravos fossem incluídos, somente $15,75 \%$ da população era considerada alfabetizada (Chalhoub 2006). Além da exclusão da participação dos debates na imprensa, o analfabetismo era decisivo para a redução da participação eleitoral. A lei eleitoral de 1881, que introduzia o voto direto em um turno, sob o pretexto de moralizar as eleições, reduziu drasticamente a participação eleitoral. Ao exigir dos eleitores saber ler e escrever, restringiu o eleitorado que era de $10 \%$ da população, a menos de $1 \%$ numa população de cerca de 14 milhões (Carvalho 1998a, p. 92).

Nessa esfera pública seletiva, nem aos personagens do mundo subalterno era permitida a participação e nem os temas que pudessem pôr essa ordem em cheque, como a escravidão e o exclusivo agrário, eram mobilizados, com o intuito de serem, de fato, enfrentados. Observando a produção dos principais publicistas do Império, tanto do campo liberal como do conservador, podemos constatar que os debates que ocorriam na cena pública se davam entre as elites e envolviam, no máximo, a população urbana letrada. Essas disputas relacionavam-se principalmente com questões políticas e institucionais, sendo relegadas para segundo plano as questões sociais. Dessa forma, os temas da mão-deobra livre e da democratização da terra não serão enfrentados e os personagens diretamente relacionados a esse mundo não serão chamados à cena pública ${ }^{4}$.

As elites intelectuais e políticas do Império buscarão, de todas as maneiras possíveis, controlar aqueles movimentos que porventura contestassem o status quo, na medida em que eles efetivamente representavam uma ameaça à fragmentação territorial. Isso pode ser evidenciado pela repressão às rebeliões escravas, aos quilombos e a qualquer forma de organização dos escravos, assim como o combate às revoltas provinciais no período regencial (1831-1840), que culminaram no Regresso Conservador, com a Lei Interpretativa do Ato Adicional (1840), a reforma do Código de Processo Penal (em 1841) e o restabelecimento do Conselho de Estado (em 1841). A própria forma como o Império lidou com o tema do sertão é exemplar nesse sentido, relacionando esse à barbárie, à violência, às paixões ferozes e à fragmentação, ao passo que o litoral, exemplificado pela Capital Federal, seria a representação da ordem, da civilização e da coesão nacional (Coser 2008, pp. 151-152).

A despeito da exclusão existente dos atores e temas aptos a participarem da esfera pública seletiva, essa aos poucos se via pressionada a democratizar-se sob a pressão de diversos segmentos. A crise da hegemonia imperial apresentou-se quando o Estado começou a mostrar-se incapaz de atender às necessidades da sociedade em modernização econômica, expansão demográfica e ampliação do leque de demandas sociais (Salles 1996). Diversos movimentos ocorridos na segunda metade do século XX - a crise de 1868, com a intervenção do Imperador na queda do Gabinete Zacarias, o surgimento do Partido Republicano em 1870, a Questão Religiosa e a Questão Militar, a Guerra do Paraguai (1864-1870), a Lei do Ventre Livre e a Lei dos Sexagenários - evidenciavam que novos interesses buscavam sua participação na esfera pública seletiva e que o Império e a ordem escravista não eram mais capazes de absorvê-los.

No contexto da crise do sistema imperial e escravista, iniciou-se, de fato, a configuração de uma esfera pública mais democrática e consistente no país. No final da década de 1860 e início dos anos 1870, vários clubes radicais foram organizados, propondo, além da descentralização político-administrativa, a 
abolição do Conselho de Estado, da Guarda Nacional, da vitaliciedade do Senado e, em alguns casos, da escravidão (Carvalho 2007). Nos anos que antecederam a Abolição (1888), não apenas a ordem imperial, mas também a escravidão perdeu visivelmente a legitimidade na sociedade brasileira, criando um ambiente favorável à proliferação de diversas associações abolicionistas, sociedades literárias e jornais em defesa do abolicionismo (Azevedo 2003).

O movimento abolicionista ganhava força em todos os setores da sociedade, não se restringindo somente aos debates na Câmara e à organização de associações contrárias à escravidão. Na imprensa - em jornais como $A$ Onda, $A$ Abolição, Oitenta e Nove, A Redenção, A Liberdade, O Alliot, A Gazeta da Tarde, A Terra da Redenção, O Amigo do Escravo, A Luta, O Federalista - bem como por meio de dezenas de panfletos e pasquins, intelectuais como Francisco de Paula Brito, André Rebouças, José Ferreira de Menezes, Silva Jardim, Luis Gama, Antonio Bento e José do Patrocínio produziam artigos a favor da abolição e, por mais que o governo tentasse recorrer a táticas reformistas, esse movimento indicava o final da escravidão no Brasil (Schwarcz 2007, p. 23). Em todos os ambientes debatia-se a questão da escravidão, seja nas ruas, teatros ou salões. Conforme destacado por Joaquim Nabuco, no país já se consolidara uma "opinião pública" aderente ao abolicionismo, com jornais e associações denunciando os horrores da escravidão, faltando unicamente vencer a batalha no Parlamento (Nabuco 2000).

Pessoas de todas as concepções políticas, de todas as cores, credos e nacionalidades organizavam manifestações, boicotes e protestos contra a escravidão. Arrecadavam-se fundos para promover alforrias e milhares de anônimos militantes, profissionais liberais, biscateiros, libertos, escravos, capoeiras, negros, mestiços, brancos brasileiros, africanos e imigrantes participavam do processo (Machado 1994; Soares \& Salles 2005). Nesse contexto de intensa agitação intelectual e política, a possibilidade da esfera pública abrir-se aos personagens do mundo subalterno e aos temas que colocassem em cheque a ordem de maneira concreta estava na ordem do dia.

Não obstante todo esse processo de mobilização, fato é que a força do movimento abolicionista desapareceu com a própria escravidão (Hasenbalg 1979, p. 154). A República que virá na esteira da abolição, inaugurada com a Constituição de 1891, não será acompanhada da inclusão social dos libertos e da população pobre em geral, assim como da democratização da terra. O novo regime não logrou romper com as relações costumeiras típicas da escravidão, sustentadas por hierarquias sociais rígidas (Rios \& Castro 2007). Todo esse processo sustou a construção de uma esfera pública democrática, que parecia se forjar no momento anterior à abolição. Nesse sentido, convém destacar que embora tenha havido uma ampliação da esfera pública no período republicano, ela ainda permaneceu pouco permeável aos personagens do mundo subalterno e aos temas "perigosos" à estabilidade da ordem. Em relação ao direito de voto, a República manteve a exclusão da maioria da população. A Constituição de 1891 eliminou a exigência da renda para o voto, mas manteve a restrição aos estrangeiros, menores de 21 anos e analfabetos. Esse último critério foi o mais decisivo para alijar parte significativa da sociedade brasileira das votações. No Censo de 1920, na população de 7 anos ou mais, o Brasil possuía $31 \%$ de alfabetizados. Entre estes, apenas 7,8\% possuíam direito de voto, mas mesmo assim poucos se utilizavam dele. No período que se estende de 1894 a 1930, a participação eleitoral girou entre $1,4 \%$ e 3,4\% da população. Somente na última eleição da Primeira República é que houve um aumento mais significativo do comparecimento às urnas, apesar desse não chegar a $6 \%$ da população. Além dos critérios legais que restringiam a participação eleitoral, havia um receio generalizado de se sair nas ruas em dias de eleição, haja vista a violência dos capangas a serviço dos candidatos. Ao reduzido número de votos e à violência 
${ }^{5}$ O processo de estabelecimento de uma ordem pública moderna nas primeiras décadas do período republicano esteve associado, em grande medida, ao discurso de criminalização de práticas "mágico-curativas", consideradas feitiçaria ou curandeirismo pelas autoridades, sobretudo quando associada aos negros (Schritzmeyer 2004) somava-se a elevada corrupção e manipulação das eleições pelos chefes locais, estaduais e nacionais (Carvalho 2001, pp. 72-73).

O tempo republicano parecia ser mais acelerado, impulsionado por novos potenciais energéticos e tecnológicos, no qual a exigência de acertar os ponteiros brasileiros com o relógio global trouxe consigo a hegemonia dos discursos técnicos, confiantes em representar a vitória do progresso e da modernização. As ações concretas desencadeadas por esses discursos - como exemplificam a repressão a Canudos e o combate à Reforma da Vacina, por exemplo - se traduziram em formas extremas de opressão quando voltadas para as populações destituídas de qualquer educação formal e afastadas dos processos decisórios. No afã do discurso modernizador, as novas elites se empenhavam em reduzir a complexa realidade social brasileira ao ajustamento em conformidade com os padrões abstratos de gestão social sob a inspiração de modelos europeus ou norte-americanos, buscando cancelar toda a herança do passado histórico do país ${ }^{5}$. Nesse sentido, prevaleceu o sentimento de vergonha em relação ao passado, aos grupos sociais e rituais da cultura que evocassem hábitos passados, sobretudo quando relacionados à população afro-brasileira (Sevcenko 1998).

As primeiras décadas do século XX testemunharam notáveis transformações na sociedade brasileira, impulsionadas, em grande medida, pela industrialização e pela urbanização. Esse processo resultou em uma ampliação significativa da pressão de novos atores sociais no sentido de participarem mais ativamente da seletiva esfera pública brasileira (Domingues 2003). À ampliação do público consumidor de bens simbólicos e de meios de comunicação "de massa", que imprimiu novos ritmos, linguagens e direcionamentos à esfera pública (Gomes 1999, p. 13), somou-se, nesse contexto, uma ampla movimentação social e intelectual de diversos segmentos da sociedade, representada por movimentos como a criação do Partido Comunista Brasileiro (PCB), a Semana de Arte Moderna de 1922 e a Coluna Prestes. Ainda que o movimento dos intelectuais ligados a essa animação intelectual e política não significasse nenhuma "ida ao povo" e nem expressasse o impulso jacobino de se pôr na direção política e cultural dos setores subalternos (Werneck Vianna 2004, p. 203), o fato é que, em decorrência das forças populares que emergiram com força nos anos 1910, a esfera pública seletiva teve que se abrir, ainda que com restrições, e a elite intelectual e política se viu na necessidade de encontrar novas formas de representar e lidar com as classes populares.

O período que se estende de 1930 a 1945 representou uma mudança significativa no processo de configuração da esfera pública no país. O governo Vargas, especialmente, com sua busca em superar o liberalismo da Constituição de 1891 e imprimir um novo ritmo à modernização tendo como ator principal o Estado, teve papel decisivo na ampliação da esfera pública e dos direitos sociais no Brasil - sobretudo com a entrada em seu âmbito das classes médias e dos trabalhadores urbanos -, ainda que esse processo tenha se dado na chave repressiva e sob o domínio da "cidadania regulada" (Santos 1979). Através da organização e dos direitos corporativos, que instituíram uma nova relação público-privado, buscou-se elevar o interesse, seja ele do empresariado, seja do operariado, ao plano da esfera púbica, mediante a subsunção do mundo do trabalho à razão do Estado (Boschi \& Diniz 1991). A despeito do autoritarismo desse período, sobretudo no contexto do Estado Novo (1937-1945), esse modelo logrou sucesso em solidificar um cenário institucional favorável à agregação e à solidarização de interesses, bem como à afirmação da prevalência da comunidade sobre o indivíduo liberal, e, em certa medida, do público sobre o privado (Werneck Vianna \& Rezende de Carvalho 2000). 
A nova ordem estabelecida em 1946, após o fim do Estado Novo, retomou o ideário liberal, ampliando as liberdades e a autonomização da vida associativa, inclusive do mundo do trabalho, mas, de maneira geral, reproduziu padrões da ordem corporativa anterior, acabando por favorecer uma concepção de república orientada por valores comunitários, na qual o indivíduo, apesar de reconhecido como dotado de autonomia e portador de direitos próprios, via-se envolvido com a ideia de bem-comum. A despeito desse processo de fortalecimento do público, as instituições permaneciam carentes de procedimentos democráticos por onde pudessem transitar os temas substantivos da democratização social do país (idem). De modo geral, é possível dizer que a partir de 1946 houve uma notável expansão da esfera pública, embora permanecessem algumas restrições importantes, como a participação eleitoral dos analfabetos, o direito de organização sindical dos trabalhadores do campo e o direito de greve dos trabalhadores urbanos e servidores públicos (Santos 2006).

O golpe militar de 1964 representou um retrocesso significativo no processo de democratização da esfera pública então em curso. A ditadura que então se instaurou no país foi marcada pelo controle sobre a esfera pública e sobre todas as formas de manifestação da vida associativa que pudessem hipoteticamente colocar em perigo a "segurança nacional", em especial os sindicatos e organizações culturais ligadas ao campo da esquerda. Nesse contexto, as concepções orientadas para a produção de consenso e de "solidarização" social que marcaram o período anterior foram substituídas pela sobrevalorização exacerbada do individualismo, com todas as consequências daí advindas para a "vertebração" associativa. A política foi travada pelo autoritarismo, ao passo que a economia ganhou autonomia e se expandiu, resultando em uma brutal separação entre o privado e o público, com a sobreposição do primeiro sobre o segundo (Werneck Vianna \& Rezende de Carvalho 2000, pp. 27-28).

Seria equivocado ignorar a expansão dos bens simbólicos no contexto da ditadura militar (Ortiz 1986), bem como a ampliação de alguns direitos, como o voto dos analfabetos, a organização dos trabalhadores no campo e o leque constitucional de bens politicamente regulados, como fundos de pensão, seguros de saúde etc. Contudo, a regressão da esfera pública foi muito mais significativa do que esses avanços pontuais, sobretudo pelo fato de a ditadura militar ter sido responsável pela regressão da capacidade estatal de assegurar aos cidadãos o exercício dos direitos constitucionais garantidos (Santos 2006, p. 116). Nesse sentido, é que se pode dizer que houve uma perda, ao longo desses anos, da ideia de uma esfera pública capaz de atuar como uma espécie de espaço de pedagogia para o civismo, na medida em que ela se converteu em uma simples alavanca dos interesses dominantes na esfera privada, com o predomínio da dimensão econômica sobre o campo da política (Werneck \& Carvalho 2004, p. 217).

O processo de degeneração da esfera pública impulsionado pelos governos militares resultou em uma série de desafios, que tiveram que ser enfrentados no contexto de redemocratização do país. A Constituição de 1988 apareceu como o coroamento de uma conjuntura de intensa mobilização da sociedade civil, constituindo-se como elemento decisivo para as lutas que tiveram curso nas décadas seguintes pela democratização da esfera pública brasileira. Admitindo a inspiração comunitária da nossa tradição republicana, com a fixação de procedimentos que viessem a favorecer a cultura do civismo, a Carta de 1988 ampliou os mecanismos de participação popular na esfera pública para além da democracia representativa por meio do estabelecimento de instrumentos participativos, como plebiscitos, referendos e conselhos (Dagnino 2002; Wampler \& Avritzer 2004). Além dos instrumentos participativos, a Constituição de 1988 também abriu novos canais de participação funcional por meio das instituições do Judiciário, recuperando o tema da pedagogia cívica exercida 
pelo Direito, suas instituições e procedimentos, de modo a ampliar as formas da representação da sociedade civil com vias próprias para chegar à esfera pública. Dessa forma, ela retomou a tradição de fazer da dimensão pública um lugar de pedagogia do civismo, agora animada pelo princípio da auto-organização e não mais pela presença tutelar do Estado (Werneck Vianna \& Rezende de Carvalho 2004, p. 222).

Nos anos recentes, diversas transformações vêm se processando na esfera pública, com destaque para a expansão e o aumento do impacto do poder do mercado, da mídia e da internet nas relações culturais, políticas e sociais. As redes sociais, em especial, têm aberto novas possibilidades de reinvenção e ampliação da esfera pública. Ainda que exista uma batalha em curso em torno da definição dos padrões de apropriação da internet, sem que se saiba ao certo se será a soberania do consumidor ou a soberania do cidadão que será privilegiada nesse processo (Eisenberg 2003b), não restam dúvidas quanto ao fato de que a rede tem atuado na ampliação da esfera pública. Conforme destacado por alguns autores, a internet tem contribuído para a configuração de diferentes formas de interação por parte das organizações cívicas, gerando conhecimento técnico-competente, memória ativa, recursos comunicativos, exigência de prestação de contas e solidariedade à distância, facilitando a operacionalização de formas variadas de participação em âmbitos distintos e expandindo o diálogo entre diferentes atores da sociedade (Maia 2007b).

\section{Esferas públicas subalternas}

A construção de uma esfera pública seletiva no país permitiu a organização de uma hegemonia por parte das classes dominantes, que logrou sustentar a constituição de uma sociedade altamente desigual. O conceito de "hegemonia" adotado aqui, embora assumindo a noção de um consenso permanentemente construído que envolve todo o processo social organizado praticamente por significados e valores específicos e dominantes e que se equilibra com o uso da força, de modo que esta pareça apoiada no consenso da maioria (Gramsci 2000, p. 95), pressupõe a ideia de que a hegemonia não se configura como um bloco concreto e fechado, imposto mediante um discurso que é assumido passivamente pelas classes populares. O conceito aqui assumido de hegemonia supõe permanentemente a ideia de antagonismo (Laclau 1990). A hegemonia é sempre viva, porque se vê impelida a se refazer, a recriar-se, a ser defendida e modificada, posto sofrer a todo o momento resistência daqueles que estão fora ou na margem, constituindo-se como um complexo de experiências e relações, com pressões e limites específicos e mutáveis (Williams 1979, p. 116).

Dessa forma, observa-se que a tendência hegemônica de repressão e controle social sobre as classes subalternas não logra extinguir as diversas concepções de mundo a que ela se contrapunha. A cultura popular, ainda que aceita, interiorizada e reproduzida, é a todo o momento relida e transformada pelos dominados, constituindo-se como uma "arena de consentimento e resistência" (Hall 2003, p. 263). Assim sendo, ainda que a construção da esfera pública seletiva tenha sido uma prática estruturante da sociedade brasileira, ela não possuiu um grau de organização tão coeso, abrindo, por conseguinte, brechas no sistema para que os subalternos resistissem e se exprimissem de diversas maneiras contra a predominância das formas sistêmicas de ação no interior dos domínios societários. Dialogando com Spivak (1988), é possível dizer que, a despeito dos subalternos dificilmente serem ouvidos, eles foram capazes de falar, de diferentes maneiras, contra os discursos hegemônicos e as práticas repressivas do cotidiano.

O que interessa destacar é o fato de que a resistência nem sempre passava por "falas públicas", podendo assumir "formas ocultas", nos termos de Scott 
(2003). O autor engloba essas formas de resistência em um conjunto de ações, que se configurariam como a "infrapolítica dos subalternos" que, ao buscarem resistir à exploração material e às formas de dominação simbólica, manteriam a resistência viva, exercendo pressão, provando e questionando os limites do permissível. Ao espaço negado no "discurso público", os setores populares exerceriam práticas e criariam formas expressivas fora de cena, constituindo "discursos ocultos" por meio dos quais buscariam romper, de alguma forma, com a aparente homogeneidade da fala oficial.

É possível conectar essa perspectiva da "infrapolítica" dos subalternos levantada por Scott com a discussão dos subaltern counterpublics abordada na primeira parte desse texto. A despeito das tentativas constantes da fala oficial para construir discursos hegemônicos a partir da esfera pública seletiva, seja por meio da violência física e/ou simbólica, fato é que, mesmo em sociedades estratificadas e extremamente desiguais como a brasileira, os subalternos lograram descobrir e articular espaços de manobras, por meios dos quais, mesmo em uma aparente homogeneidade, construíram "discursos ocultos", muitas vezes sustentados em performances que, tornando ou não "falas públicas", testavam a todos os momentos os limites da ordem. Em sociedades marcadas pela violência permanente, "o silêncio, o implícito, o invisível são, frequentemente, mais importantes do que o manifesto" (Chauí 1986, p. 33).

Nesse sentido, é possível perceber que as ações dos segmentos subalternos poderiam assumir caráter reativo, localizadas em ações coletivas - como o exemplificam as diversas formas de protestos abertos contra o sistema que se desenrolaram no decorrer da história brasileira - ou irromper por outras formas de manifestação mediante a "manutenção de todo um circuito de contatos sociais, trocas culturais e práticas ritualizadas em redes clandestinas, cercadas por códigos de silêncio e jargões indecifráveis, acessíveis apenas aos iniciados", que se construíam como "meio peculiar de garantir-se contra as invasões da autoridade arbitrária e intolerante" (Sevcenko 1998, p. 32). Essa segunda forma, caracterizada pela resistência difusa - "como na irreverência do humor anônimo que percorre as ruas, nos ditos populares, nos grafites espalhados pelos muros das cidades" (Chauí 1986, p. 63) -, foi mais presente na história brasileira e configurou um tipo de manifestação consciente dos subordinados em contextos nos quais o "discurso oculto" era mais seguro do que a "fala pública". Dessa forma, os setores populares, no Brasil, foram capazes de resistir à imposição hegemônica construída na esfera pública seletiva, logrando estabelecer, em determinados momentos, esferas públicas subalternas, que a despeito de não conseguirem alçar suas demandas à esfera pública elitista e, por conseguinte, disputarem a hegemonia da sociedade, foram capazes de construir outros discursos, ancorados em uma cultura popular repleta de força inovadora, criatividade e potencialidade.

É importante destacar que a existência de esferas públicas subalternas não confere automaticamente a elas um caráter virtuoso. Ao discutir acerca da existência dos subaltern counterpublics, Nancy Fraser faz uma importante ressalva, destacando o fato desses públicos não serem necessariamente democráticos e igualitários, não obstante serem fundamentais para a expansão do espaço discursivo, sobretudo em sociedades estratificadas:

"I do not suggest that subaltern counterpublics are always necessarily virtuous. Some of them are explicitly antidemocratic and antiegalitarian, and even those with democratic and egalitarian intentions are not always above practicing their own modes of informal exclusion and marginalization. Still, insofar as these counterpublics, they help expand discursive space. In principle, assumptions that were previously exempt from contestation will now have to be publicly argued out. In general, the proliferation of subaltern counterpublics means 
6 "Não sugiro que as esferas públicas subalternas sejam sempre virtuosas. Algumas delas são explicitamente antidemocráticas e antiigualitárias, e mesmo aquelas com intenções democráticas e igualitárias eventualmente praticam seus próprios modos de exclusão informal e marginalização. Ainda assim, na medida em que são esferas públicas, eles ajudam a expandir o espaço discursivo. Em princípio, assumpções que foram previamente excluídas da contestação terão de ser agora publicamente discutidas. Em geral, a proliferação das esferas públicas subalternas significa uma ampliação da contestação discursiva, e isso é uma coisa boa em sociedades estratificadas" (Tradução do Revisor).

7 Caso desejemos retroceder no tempo para analisar espaços de sociabilidade dos segmentos subalternos que, inclusive, permaneceram existindo no decorrer do período imperial, poderíamos destacar a importância das irmandades religiosas constituídas pelos negros. Sobre esse tema, ver Reis (1997), Souza (2002) e Borges (2005).

${ }^{8}$ Entre os estudos que seguiram essa perspectiva, podemos destacar as análises a widening of discursive contestation, and that is a good thing in stratified societies"6 (Fraser 1992, p. 124).

A perspectiva da existência de esferas públicas subalternas, ainda que não necessariamente virtuosas, abre um diálogo direto com pesquisas recentes que vêm sendo desenvolvidas por diversos historiadores brasileiros no sentido de criticar aquilo que seria concebido como "paradigma da ausência". Esse paradigma se sustentaria na ideia segundo a qual setores populares no Brasil, em flagrante contraste com os povos de outros paradigmas nacionais, em especial os europeus, seriam bestializados, passivos e pouco afeitos à sociabilidade e à organização. Em uma perspectiva contrária, estudos historiográficos orientados pelo "paradigma da agência" analisam concretamente as negociações, escolhas e decisões que os segmentos subalternos estabeleceram tanto entre eles mesmos, quanto frente aos poderes constituídos (Chalhoub \& Silva 2009). Mais do que julgar se o nosso povo seria naturalmente propício ao "insolidarismo social", como estabelecido classicamente por Oliveira Vianna, em Populações Meridionais do Brasil (1920), e seguido por outros estudiosos nas décadas seguintes, objetiva-se inquirir acerca das redes sociais efetivamente estabelecidas pelos segmentos subalternos.

Partindo dessa perspectiva é possível dizer que, assim como destacado no tópico anterior, esboços de esferas públicas subalternas podem ser encontrados no Brasil desde a Independência do país, ainda que a consolidação das mesmas tenha se processado no contexto da crise do império e da escravidão ${ }^{7}$. Conforme demonstrado por Ribeiro (2003), ao contrário "de uma Independência feita placidamente às margens do Ipiranga", diversas manifestações populares ocorreram na Corte nesse contexto, envolvendo, inclusive, a população "de cor". Prova dessa movimentação foi o esforço das forças policiais à época no sentido de explorar as ruas e as vielas atrás de papéis e proclamações "incendiárias" e de ajuntamentos perigosos de "negros". Além de coibir panfletos "insidiosos" e punir com rigor as desordens e os ajuntamentos, buscava-se proibir o funcionamento de tavernas, lojas e botequins que continuassem abertos ao público em horas indevidas, com o intuito de impedir que aquele processo adquirisse uma feição radicalizada.

No contexto das revoltas regenciais, a luta política atingiu níveis nunca antes alcançados, abrindo espaço para que discursos alternativos fossem formulados com maior sistematicidade nas esferas públicas subalternas. Nesse momento de "explosão da palavra pública" (Morel 2003, p. 10) - marcado por agitações na Bahia (Sabinada, de 1837 a 1838), Pará (Cabanagem, de 1832 a 1835), Rio Grande do Sul (Farroupilha, de 1835 a 1845), Maranhão (Balaiada, de 1838 a 1841) -, a despeito das diferenças existentes e do grau de radicalismo de cada um, os movimentos contestatórios valorizaram as manifestações públicas coletivas como forma legítima de ação política. Envolvendo pessoas das mais diversas camadas sociais, essa "politização das ruas" - inclusive, mediante a mobilização de panfletos e jornais - animou a resistência à construção de projetos de "cima para baixo" e atuou como lócus de exercício da cidadania (Basile 2007, pp. 56-57).

Mesmo entre os escravos foi possível a construção de redes de sociabilidade e organização coletiva. Muitas páginas já foram gastas e ainda o serão no debate a respeito da "resistência escrava". À abordagem de Gilberto Freyre, em Casa Grande e Senzala que, segundo seus críticos, suavizava as relações entre senhores e escravos no Brasil colonial, seguiram os estudos que procuravam enfatizar apenas a rigidez e a violência do regime escravista, demonstrando o cativo somente como vítima passiva e objeto da ação dos senhores ${ }^{8}$. Por outro lado, algumas pesquisas buscaram realçar que somente através das fugas, da violência contra os senhores e da formação de quilombos, que os cativos 
da chamada "escola paulista de sociologia", especialmente os estudos de Cardoso (1962) e Ianni (1978). negariam a escravidão. Alguns líderes dessas revoltas eram transformados em heróis e os pequenos mocambos ou revoltas rapidamente sufocadas ou até mesmo a resistência cotidiana eram considerados de menor ou de quase nenhuma importância histórica (Gomes 2005).

Visando contestar a dicotomia destes estudos que colocavam de um lado "Zumbi dos Palmares" - o escravo que luta "revolucionariamente" contra o sistema - e de outro "Pai João" - o cativo submisso e conformado -, surgiram novas abordagens baseadas em profundas pesquisas empíricas, assim como dialogando com outros aportes teóricos e metodológicos, que visavam reexaminar e problematizar a resistência escrava em diferentes ópticas. Esses estudos apontam para o fato de que os escravos negociaram mais do que lutaram abertamente contra o sistema (Reis \& Silva 1989). Essas novas abordagens, que passaram a valorizar o escravo como um agente histórico, preocuparam-se em evidenciar que antes de chegar ao Brasil essas pessoas possuíam uma história e uma cultura, que influenciarão decisivamente as relações estabelecidas entre eles, seus senhores e a sociedade (Priore \& Venâncio 2004).

As pesquisas historiográficas desenvolvidas nas últimas três décadas têm procurando enfatizar os aspectos multifacetados da resistência negra durante a escravidão, visando demonstrar de que forma os cativos reelaboraram, reorganizaram e transformaram, sempre que possível, o universo em que viviam, desenvolvendo noções próprias sobre o conceito de liberdade (Chalhoub 1990). As variadas formas de resistência escrava evidenciam que não somente "reagiam", mas que "agiam", enfrentando processos de lutas, conflitos e acomodações, desenvolvendo uma contracultura fora da órbita da política formal, que se valeu fundamentalmente da performance, nos termos de Gilroy (2001). Embora os senhores procurassem controlar sistematicamente a população escrava, os cativos buscavam modificar seus destinos, alargando seus espaços em busca de autonomia dentro da escravidão, ampliando e reinventando as estratégias de resistência, valendo-se principalmente dos "discursos ocultos" em um momento no qual a crítica aberta era demasiadamente arriscada.

Conforme destacamos no tópico anterior, sobretudo a partir das décadas de 1870 e 1880, houve um aumento significativo da pressão de diferentes setores da opinião pública em favor da abolição da escravidão. Somado ao aumento da resistência escrava, essas manifestações contribuíram para a configuração de um contexto no qual "discursos ocultos" e personagens outrora relegados às esferas públicas subalternas pudessem participar com maior força dos embates na esfera pública seletiva. Em seu estudo sobre associativismo na América Latina, Leonardo Avritzer chama a atenção para a criação, a partir da década de sessenta do século XIX, de diversos clubes abolicionistas no Rio de Janeiro, Ouro Preto e Recife, os quais se destacariam pela organização de manifestações públicas e pela utilização da imprensa "para a realização de discussões com conteúdo moral na esfera pública” (Avritzer 1997, p. 158). Contudo, Avritzer não explora de forma mais sistemática o impacto desse movimento para a constituição da esfera pública no país. Em estudos recentes, Angela Alonso parte de hipótese diferenciada, sustentando a importância das mais de duzentas associações abolicionistas que foram constituídas desde o início da campanha antiescravista até 1888 não apenas no sentido de transformar a agenda abolicionista em um tema do debate público, mas em trazer para a vida política "outsiders políticos", como ex-escravos, mulheres e, até mesmo, crianças, expandindo, dessa maneira, "tanto o público quanto o espectro de agentes sociais praticantes da política" (Alonso 2011, p. 189).

Contudo, importa destacar que, findo o processo de Abolição, os ex-escravos, libertos por alforria, ingênuos (nascidos no pós-1871) e a população de livres e pobres, em geral, tiveram que lidar com uma nova etapa da violência 
física e simbólica, forçando-os a encontrar novas performances habilidosas de resistência e manifestação. Nesse novo contexto, os setores subalternos tiveram que, através da conquista, do convencimento e da contínua produção de interpretações, buscar espaços por meio dos quais fosse possível resistir ao projeto disciplinar construído na esfera pública seletiva que instituiu juridicamente a figura do "cidadão". Essa resistência, por sua vez, longe de constituir exemplo de crítica social envolta num discurso político único, esteve mais presente em situações aparentemente triviais, experimentadas em todos os momentos "em que esteve em jogo o poder do exercício da igualdade para homens e mulheres marcados por origem social ou cor" (Cunha \& Gomes 2007, p. 14).

A primeira quinzena republicana, que vai de 1889 até a Revolta da Vacina em 1904, testemunhou a busca das esferas públicas subalternas no sentido de se manifestarem com mais ênfase, sobretudo durante o período jacobino que durou até 1897, marcado por assassinatos políticos, golpes de Estado, revoltas populares, greves, rebeliões militares, guerras civis, com elevada participação popular. Apesar disso, a paz oligárquica inaugurada a partir do governo Campos Sales (1898-1902) promoveu a verticalização da ordem política através da exclusão do demos e do controle sobre a dinâmica legislativa e sobre a geração de ações coletivas legítimas (Lessa 1999), consolidando o regime mediante o alijamento da participação popular. Conforme destacado por José Murilo de Carvalho, "organizar um governo republicano viável significava afastar-se da democracia" (Carvalho 2001, p. 62);

Não obstante as dificuldades advindas da violência vertical e horizontal esta última relacionada ao reduzido mercado de trabalho e aos conflitos existentes entre os operários, principalmente brasileiros e imigrantes (Chalhoub 2001) -, o movimento operário, que começava a se organizar nesse período, logrou criar espaços por meio dos quais pudesse se manifestar. Antes dos anos 1920, não havia propriamente uma "cultura operária”, mas sim “culturas militantes", em particular a dos anarquistas, que se pretendiam alternativas à cultura dominante (Batalha 2004, p. 99). Aliás, ao contrário do que alguns estudos procuraram evidenciar e do que a memória varguista tentou construir, o movimento operário não se constituiu a partir de 1930. Além da eclosão de greves, da criação de sindicatos, sobretudo por ofício, federações e confederações, da realização de congressos e encontros, havia uma vida popular ativa, inclusive com a organização de jornais, panfletos e manifestos, ainda que efêmeros, que buscavam disputar a opinião entre o reduzido número de trabalhadores (Batalha 2000). A título de exemplo, basta observar a proliferação de jornais anarquistas nesse período (Carvalho 1987, pp. 56-58), constituindo esferas públicas subalternas que buscavam, mesmo em uma cultura marcada pela violência vertical e horizontal, difundir suas ideias e mobilizar os trabalhadores. Nos momentos de maior mobilização, como as greves de 1902-1903, 1906-1907, 1917-1919 ou o movimento contra a carestia de vida de 1913, as ações coletivas transcendiam os interesses corporativos, envolvendo muito mais gente do que o número restrito de trabalhadores (Batalha 2003, pp. 172-173). Nessas ocasiões, os movimentos foram duramente reprimidos pelas forças da ordem. Assim como evidenciado no episódio da Revolta da Vacina (1904), cuja "repressão brutal e indiscriminada" buscou "eliminar da cidade todo o excedente humano, potencialmente turbulento" (Sevcenko 1993, p. 70), qualquer tentativa de organização popular implicava em intensa violência vertical ${ }^{9}$.

Enquanto a grande maioria da população permanecia alijada de espaços institucionalizados de organização e do acesso à esfera pública seletiva, uma pequena parte procurava se manifestar publicamente através de queixas em jornais relativas à segurança, à qualidade dos serviços públicos urbanos e às condições de vida (Silva 1988) e/ou recorrendo ao poder Judiciário não apenas para reagir contra a repressão, mas para reivindicar direitos novos ou pretéritos

9 Outra situação exemplar de repressão a um movimento popular foi aquele verificado quando da Revolta da Chibata, que ocorreu no Rio de Janeiro entre os dias 23 e 26 de novembro de 1910 . 
${ }^{10}$ Após o fim do Estado Novo, haverá um "renascimento" das organizações negras, com destaque para a União dos Homens de Cor (UHC), grupo fundado em Porto Alegre em 1943 e que cinco anos mais tarde se ramificou por mais dez estados da Federação mediante a mobilização de periódicos da imprensa negra (Silva 2003). Variados estudos recentes vêm procurando destacar a importância do "protesto negro" no decorrer do século XX, que culminaram nas diversas conquistas simbólicas junto ao poder institucional realizadas nos últimos anos (Rios 2012). considerados legítimos (Ribeiro 2009), ao passo que outra encontrava nas diversas associações existentes espaços nos quais pudessem assegurar um amparo através da proteção frente à doença, à velhice, ao desemprego e às condições adversas ligadas à morte de um familiar. Além disso, muitas dessas associações funcionavam como espaços de lazer e solidariedade, bem como contribuíam para o reforço e ressignificação de identidades coletivas, funcionando como instrumentos facilitadores do processo de construção de cidadania e como instrumentos de pedagogia política (Viscardi \& Jesus 2007).

Contrariando diversas análises, diferentes pesquisas historiográficas recentes vêm procurando demonstrar que, desde o Império, se consolidou uma rica vida associativa entre os setores populares, possibilitando a construção de esferas públicas subalternas. Esse processo, contudo, era controlado pelas forças da ordem e nem sempre o processo de obtenção da permissão para o funcionamento dessas associações era tranquilo, sobretudo quando se tratavam de organizações coletivas de negros (Batalha 1999; Chalhoub 2007; Jesus 2007). Na Primeira República, em um contexto de afirmação de uma ideologia liberal, que convivia com uma sociedade civil ainda muito fragmentada, o fenômeno associativo se ampliou de maneira significativa, sendo criadas diversas associações não apenas de ajuda mútua, mas também étnicas, culturais e recreativas (Carvalho 1987, pp. 143-145; Batalha 2004).

Os anos 1920 e 1930 testemunharam processos de transformação nos espaços de sociabilidade dos setores subalternos, em geral, e dos trabalhadores, em particular, impulsionados pelo aceleramento da urbanização e da industrialização, que estimularam a entrada de novos atores e interesses na esfera pública seletiva, sobretudo devido à ampliação do acesso à educação. A título de exemplo, basta observar que em 1922 foi fundado o Partido Comunista Brasileiro (PCB), que a despeito de ser significativamente constituído por segmentos da classe média, representava uma primeira tentativa dos segmentos populares de se organizarem partidariamente para intervir na esfera pública. Também nesse contexto diversos movimentos de "minorias" começaram a se organizar, pressionando a esfera pública seletiva com suas reivindicações. Nos anos 1930, após mobilização por parte da imprensa negra, foi criada a "Frente Negra Brasileira", movimento social que se transformou em partido político, para ser extinto em 1937, com o Estado Novo (Guimarães 2004, p. 274) ${ }^{10}$. Além disso, a pressão das mulheres por uma participação mais efetiva na esfera pública também começará a ganhar contornos mais claros a partir desse contexto. Nos anos subsequentes, alternando momentos de avanços e retrocessos, o movimento feminista logrará consolidar esferas públicas subalternas capazes de tecer discursos alternativos ao status quo (Pinto 2003).

Não há como deslocar a análise da reorganização das esferas públicas subalternas a partir da década de 1930 sem que se tome em conta a relação contraditória de inclusão e repressão, estabelecida pelo Governo Vargas e os governos que o seguiram até 1964, sobretudo devido às relações heterônomas estabelecidas entre eles e o movimento operário que então se fortalecia. Durante anos, as relações entre esses governos e os trabalhadores foram analisadas sob a chave explicativa do conceito de "populismo" que, em linhas gerais, trazia consigo a ideia de uma política de massas, sob a liderança de um líder carismático, que agregava para dentro do Estado o movimento operário organizado, implicando, de um lado, em pequenos benefícios aos trabalhadores, e por outro, na cooptação dos mesmos pelo regime então em vigor, impedindo que os trabalhadores adquirissem consciência e sentimento de classe (Weffort 1973). Nos últimos anos, contudo, a interpretação "populista" tem sido alvo constante de críticas e revisões. Diversos estudos vêm sendo desenvolvidos, questionando a pertinência da utilização do termo "populismo" para compreensão desse período da história brasileira, recusando-se a noção de uma posição política 
passiva dos trabalhadores e destacando sua atuação como sujeitos, em permanente interlocução com o Estado, que embora fosse marcada por uma relação assimétrica, não se constituía somente pela mera repressão e cooptação. A ideia de "pacto trabalhista" visa alcançar justamente o objetivo de evidenciar que embora desiguais, as relações entre Estado e classe trabalhadora não eram marcadas exclusivamente pelo predomínio total do primeiro sobre a passividade da segunda (Gomes 1988; Ferreira 2001).

Dessa maneira, as pesquisas passaram a valorizar a atuação dos segmentos populares como agentes desse processo, que buscavam, nos meandros do sistema autoritário, encontrar maneiras de conseguir benefícios concretos e, se possível, construir esferas públicas subalternas capazes de questionar a ordem em questão. O processo de fortalecimento das esferas públicas subalternas teve novo ânimo principalmente a partir do início dos anos 1950 e 1960, quando diversos movimentos sociais em constituição passaram a pressionar cada vez mais a esfera pública seletiva para promover reformas estruturais profundas, inclusive contando com a participação dos trabalhadores do mundo agrário mediante a organização das Ligas Camponesas e com a difusão do sindicalismo rural. O golpe militar de 1964 veio interromper esse andamento e constituiu-se como um interregno de perseguição, censura e repressão a quaisquer tentativas de organização popular.

O período da ditadura militar foi uma época por excelência da constituição de "discursos ocultos", na formulação de Scott (2003) que, devido à repressão, buscavam expressar principalmente por meios informais sua oposição em um momento no qual a crítica aberta era demasiado arriscada. Aquele mundo que, aparentemente, comportava-se de maneira submissa diante daquele contexto de violência institucionalizada, movia-se por meio de performances habilidosas de resistência na luta pelo reestabelecimento do Estado de Direito. Foi justamente a partir desses discursos ocultos, tornados aos poucos "falas públicas", que começaram a se constituírem esferas públicas subalternas pujantes e contestatórias da ordem. O período de redemocratização foi marcado pela emergência de novos atores que buscava pressionar a esfera pública seletiva para fazer ouvir suas vozes e pressionar pela consecução de seus interesses (Sader 1995).

A mobilização de diversos setores da sociedade civil - como a Ordem dos Advogados do Brasil (OAB), a Associação Brasileira de Imprensa (ABI), a Sociedade Brasileira para o Progresso da Ciência (SBPC), alguns setores da Igreja Católica, instituições científicas públicas e privadas, assim como movimentos de minorias - no decorrer destes anos teve como símbolo principal as reivindicações dos metalúrgicos no $\mathrm{ABC}$ paulista, que desembocou na criação do Partido dos Trabalhadores (PT) e da Central Única dos Trabalhadores (CUT). Essa movimentação evidencia o grau de organização da sociedade brasileira e dos movimentos sociais, que desejavam influir decisivamente no processo de construção da nova democracia. O aparecimento de novos movimentos sociais - ligados às mulheres, aos negros, às causas ambientais, à reforma agrária e urbana -, vitalizando a infraestrutura comunicativa do mundo da vida, desencadeou uma ampla discussão de temas até então não problematizados, tornando-os questões de relevância social e passíveis, por conseguinte, de intervenção política (Costa 2002).

À guisa de conclusão desta seção, convém destacar que, no decorrer da história brasileira, a música e a religião talvez tenham sido as principais formas de expressão e sociabilidade dos setores populares na busca pela construção de esferas públicas subalternas. Durante o período imperial, por exemplo, paralelamente às festas oficiais organizadas pela realeza, havia uma profusão de festas populares, como as "cavalhadas", "congadas", "batuques", "folia de Reis" e "festa do Divino", que tinham como palco a área central da cidade (Schwarcz 
11 Para uma discussão sobre esses aspectos, vale consultar vários dos artigos contidos nos três volumes da coleção Decantando a República. Um inventário histórico e político da canção popular moderna brasileira (Eisenberg, Cavalcante \& Starling 2004).

12 Para uma discussão sobre a relação entre religião e esfera pública no Brasil, ver Montero (2006).

\section{Conclusões}

\footnotetext{
13 Alguns trabalhos vêm procurando, nos últimos anos, chamar a atenção para a necessidade de se pesquisar a modernidade no Brasil de
}

1998, pp. 247-278). As práticas musicais no decorrer da história brasileira fossem elas organizadas em senzalas, quilombos, rodas de samba, sedes das sociedades carnavalescas, salões de bailes populares ou teatro de revistas faziam parte da vida, do lazer e das demandas políticas de setores populares e, embora muitas das suas modinhas, lundus, sambas, músicas de protesto, rap, hip hop, funk etc. tenham sido alvo de repressão, as canções produzidas pelos subalternos - "irreverentes, obscenas ou graciosas" - lograram alcançar os espaços da esfera pública seletiva ${ }^{11}$.

Em relação à religião, a despeito de não colocarem em cheque a institucionalidade oficial, os setores subalternos a interpretaram de maneira própria, apropriando-se dos símbolos e crenças de acordo com suas experiências e necessidades, mesclando-os com outras formas não necessariamente oficiais para o exercício da religião. Houve, no decorrer da história, uma permanente tensão entre o catolicismo da hierarquia eclesiástica e o catolicismo popular, assim como no interior destes, revelando a pluralidade de possibilidades de apropriação existentes. Essa sociabilidade, portanto, não era organizada pela institucionalidade oficial católica, embora essa fornecesse o arsenal interpretativo sobre o qual o mundo popular edificava novas interpretações. Trata-se, portanto, de uma religiosidade aberta, em constante movimento e criação, que envolve rezadores, curandeiros, pais e mães-de-santo, benzedeiras etc. e supõe uma vida comunitária ativa. As festas e a profusão de irmandades e associações religiosas revelam um mundo popular que se associava e continua se associando, lendo de maneira criativa as tradições, que tentam regular essas manifestações ${ }^{12}$.

Dessa forma, é possível perceber que, não obstante a existência da violência vertical e horizontal às quais os setores subalternos estiveram submetidos no decorrer da história brasileira, eles buscavam se organizar por diferentes meios e de diversas formas, seja para resistir, seja para criar novos mundos alternativos àquela ordem repressora, pressionando, de diversas maneiras, a esfera pública seletiva. Os populares "possuíam noções próprias de justiça e, quando envolvidos em situações de conflito, seguiam rituais de conduta que mostravam apego a valores muitas vezes opostos àqueles prezados pelas classes dominantes" (Chalhoub 2001, p. 209). Daí, a permanente postura repressiva e suspeita dos segmentos dominantes diante de possíveis manifestações dessas esferas públicas subalternas.

Conforme discutiu-se no presente artigo, desde o começo do século XIX, ao lado das duas instituições fundamentais da modernidade, quais sejam, o Estado e o mercado, foi construída no Brasil uma esfera pública, ainda que a forma de sua configuração tenha ocorrido de maneira seletiva. Pari passu a esse processo, houve a construção de esferas públicas subalternas que procuraram resistir de diferentes maneiras aos discursos hegemônicos, sobretudo por meio de performances e "falas ocultas", embora tenham ocorrido momentos nos quais elas tenham se tornado "discursos públicos", adquirindo mais força para disputar visões de mundo com aqueles formulados na esfera pública seletiva.

A percepção da existência dessas esferas públicas demanda não apenas um olhar histórico mais acurado, mas um movimento no sentido de perceber outras formas de manifestações como legítimas para a configuração de esferas públicas que não se prendam ao paradigma organizacional do mundo europeu ou norte-americano ${ }^{13}$. Sobretudo quando se analisa a dinâmica das esferas públicas subalternas, deve-se ter em mente que formas de organização e associativismo no Brasil não foram as mesmas do modelo "classista" dos padrões europeus, e os discursos mobilizados na esfera pública não adotaram necessariamente 
modo a superar modelos que tomam a ideia de modernidade a partir de um referencial único, e que têm como corolário a avaliação da modernidade brasileira associada às ideias de "ausência" e "inautenticidade". Para uma discussão teórica sobre esse aspecto, ver Tavolaro (2005).

14 A obra de Spivak (1988), em especial, inspirada pela experiência indiana, abre um campo importante de investigação sobre estes públicos nas "periferias" ao problematizar a ideia segundo a qual um sujeito, como o movimento operário seria o portador do discurso subalterno. Para a autora, a experiência periférica aponta para a heterogeneidade de vozes que constroem suas falas e subjetividades precárias em contextos diferenciados do paradigma europeu.

15 A despeito de reafirmamos o fato das esferas públicas subalternas não serem necessariamente democráticas e igualitárias, reproduzindo padrões de hierarquia - inclusive, por estarem inseridos em uma sociedade que possui uma cultura política fortemente autoritária -, dar voz a eles implica na expansão do espaço discursivo, permitindo conferir primazia ao princípio de integração social e da solidariedade, a partir da perspectiva dos próprios participantes.

16 Habermas (1990) critica Rousseau pelo fato deste, ao acreditar que a virtude cívica dos cidadãos individuais proporcionará per se a constituição de um conjunto de cidadãos orientados para o bem comum, dar preferência mais ao "consenso dos corações" do que aos argumentos racionais, desejando ele, por consequência, uma democracia sem debate público. A moralidade que Rousseau advogava que residisse nas motivações e virtudes dos indivíduos deveria estar, segundo Habermas, ancorada no próprio processo comunicativo, operado no padrões "críticos racionais" centrados na dinâmica dos interesses, mas assumiram, diferentemente, mecanismos mais "expressivistas", carnavalescos e lúdicos, muito mais ancorados na emoção, nos sentimentos, no humor, na ironia e na paródia do que nas palavras de ordem prontas e bem formuladas. Nesse sentido, essa perspectiva de pensar os discursos subalternos a partir de lógicas distintas do mundo europeu estabelece um diálogo direto com os trabalhos produzidos em torno do grupo dos Subaltern Studies, por autores como Gayatri Spivak, Ranajit Guha, Dipesh Chakrabarty e Partha Chatterjee que, em diálogo direto com as formulações de Gramsci, contribuem para lançar luz sobre novas possibilidades de investigação em torno dos públicos subalternos ${ }^{14}$.

Talvez um dos principais méritos de Gilberto Freyre (1990) tenha sido justamente o de perceber o caráter solidário dessa sociabilidade popular, herdada dos quilombos e atualizada pelos mocambos, marcada pela miscigenação e pela pluralidade, que permitiria a nós, inclusive, um ingresso distinto à modernidade. A importância da cultura popular, nas suas variadas expressões em nossa vida nacional atuou como o médium "privilegiado de reprodução e reinvenção da linguagem dos sentimentos, com sua ambição de reabrir o mundo à potência da multidão" (Barboza Filho 2008, pp. 33-34). Observada pelas lentes da linguagem dos sentimentos, essa multidão fez do improvável a marca da sua presença e o programa de sua potência, atuando como combustível de um processo de democratização, ainda que numa chave passiva ${ }^{15}$.

Diversos autores criticaram nos últimos anos a ausência de um vazio motivacional na teoria habermasiana, destacando o fato de seu procedimentalismo ser demasiadamente racionalista (Ottmann 1992, p. 65) ${ }^{16}$. As críticas mais sistemáticas, nesse sentido, do ponto de vista teórico, foram produzidas por autores associados ao chamado comunitarismo, como Charles Taylor, Michael Sandel, Alasdair MacIntyre e Michael Walzer. A despeito das diferenças existentes em seus trabalhos, os comunitaristas criticaram o procedimentalismo racionalista, universalista e deontológico presente não apenas nos trabalhos de Habermas, mas também de John Rawls, que desconsideraria a importância dos valores e configurações morais historicamente partilhados de uma comunidade para se pensar normativamente questões de justiça e democracia ${ }^{17}$.

Rubem Barboza Filho estabelece uma crítica pertinente ao modelo de democracia deliberativa habermasiano ao enfatizar que não obstante ele contemple as exigências de uma razão bem compreendida, recusando a inevitabilidade de sujeição ao interesse egoísta e ao cálculo estratégico, ele incorpora apenas parcialmente o "sentimento bem compreendido", isto é, os valores, que seriam elementos fundamentais para pensar analiticamente e normativamente formas de vida democráticas. Nesse sentido, a formulação habermasiana torna secundária a importância dos processos "expressivistas" e dos sentimentos para a construção da democracia (Barboza Filho 2003) ${ }^{18}$. No caso do Brasil, formas cada vez mais aperfeiçoadas de organização democrática só poderão ser consolidadas caso sejam acompanhadas de uma vontade ou de um "sentimento de democracia", que reinvente a nossa tradição expressivista, presente de maneira intensa na nossa cultura popular, em vez da sua substituição simplista pela matriz utilitarista do liberalismo ${ }^{19}$.

Ao estabelecer um paralelo comparativo entre as obras de Habermas e Bakhtin, Gardiner (2004) aponta para o fato de o primeiro concentrar sua atenção em uma forma de racionalidade abstrata, distante das situações da vida cotidiana. Dessa forma, separando as razões morais das considerações sobre justiça e colocando no primeiro plano as formas de reivindicação de validade, Habermas teria dedicado pouca atenção ao humor, à ironia e à paródia, idealizando o ato de fala como uma situação de pureza. Bakhtin, ao contrário, sem cair no relativismo, colocar-se-ia de maneira crítica ao universalismo abstrato 
interior da esfera pública e voltado para a formação da opinião e da vontade coletiva.

17 Para uma discussão mais sistemática sobre esse aspecto, ver Walzer (1990) e Taylor (2000).

18 Em ensaios recentes, sobretudo em seus estudos sobre religião e esfera pública, embora venha admitindo a pertinência do papel dos valores, Habermas (2001) continua a aprisioná-los nos procedimentos enquanto condições prévias à democracia, conferindo-lhes um papel secundário no desenho normativo do deliberacionismo.

19 O brasilianista Richard Morse (1988), em sua obra $O$ espelho de próspero, foi um dos primeiros autores a chamar a atenção para as potencialidades civilizatórias da "opção ibérica" com suas conotações organicistas e comunitárias, quando comparada com o mundo anglo-saxão, sobretudo por sua porosidade à diversidade do gênero humano, o seu ideal rousseauniano de justiça e da vontade geral como instrumento político de construção de identidade e emancipação, bem como por sua crença em uma realidade social transcendente ao indivíduo e a vitalidade do elemento lúdico, fundamental para o desenvolvimento cultural e a improvisação social. kantiano, focalizando o fazer prático diário e as possibilidades de transformação e mudanças de significados em contextos concretos diferenciados. Essa percepção de Bakhtin pode ser articulada com o debate sobre as esferas públicas subalternas no Brasil, posta a sua valorização da pluralidade de vozes existentes no mundo público que, apesar de combinarem consentimento e resistência, questionam e subvertem a ordem a todo o momento, por meio de estratégias carnavalescas, marcadas pela inventividade e pela criatividade.

Nesse sentido é que se coloca a tarefa da construção de estruturas específicas de captação dos interesses e públicos subalternos, não apenas mediante a força expressiva dos argumentos, mas também das performances, da linguagem dos sentimentos e das formas não verbais de comunicação. As expressões culturais, contudo, é importante dizer, não se apresentam em sua concretude como projeto político, devendo, para tanto, serem apropriadas por grupos sociais mais amplos, que as reinterpretarão e as orientarão politicamente (Ortiz 1986, p. 142). Conforme destacado pelo próprio Habermas, a soberania do povo, diluída comunicativamente, não pode impor-se apenas através de discursos públicos informais para gerar poder político, devendo sua influência abranger também as deliberações democráticas da formação da opinião e da vontade, assumindo a forma autorizada (Habermas 1997, p. 105). O desafio que se coloca, portanto, relaciona-se à necessidade da conexão das instituições políticas com essas esferas públicas subalternas, de modo a converter suas potencialidades organizativas em uma verdadeira política de transformação do país.

Fernando Perlatto (fperlatto@yahoo.com.br) é Doutor em Sociologia pelo Instituto de Estudos Sociais e Políticos (IESP), da Universidade do Estado do Rio de Janeiro (UERJ), e Professor Adjunto do Departamento de História e do Programa de Pós-Graduação em História da Universidade Federal de Juiz de Fora (UFJF)

\section{Referências}

Alencastro, L.F. 1997. Vida privada e ordem privada no Império. In Corte e a modernidade nacional. V. 2. São Paulo: Companhia das Letras.

. 2001. Joaquim Nabuco - "Um estadista no Império". In L.D. Mota, ed. Um banquete no trópico. Introdução ao Brasil. V. 1. São Paulo: Editora Senac.

Alonso, A. 2011. Associativismo avant la lettre - as sociedades pela abolição da escravidão no Brasil oitocentista. Sociologias, 13(28), pp. 166-199.

Arjomand, S. 2001. Perso-Indian Statecraft, Greek Political Science and the Muslim Idea of Government.International Sociology, 16(3), pp. 455-473.

Asen, R.; Brower, D.C. 2001. Counterpublics and the State. New York: State University of New York.

Avritzer, L. 1996. A moralidade da democracia: ensaios em teoria habermasiana e teoria democrática. São Paulo/Belo Horizonte: Perspectiva/Editora da UFMG.

1997. Um desenho institucional para o novo associativismo. Lua Nova, 39, pp. 149-174.

2000. Entre o diálogo e a reflexividade: a modernidade tardia e a mídia. In L. Avritzer; J.M. Domingues, eds. Teoria social e modernidade no Brasil. Belo Horizonte: Editora da UFMG.

2002. Democracy and the Public Space in Latin America. Princeton: Princeton University Press. 
Avritzer, L.; Costa, S. 2004. Teoria crítica, democracia e esfera pública: concepções e usos na América Latina. Dados, 47(4), pp. 703-728.

Azevedo, C.M.M. 2003. Abolicionismo: Estados Unidos e Brasil, uma história comparada (século XIX). São Paulo: Annablume.

Baker, K.M. 1992. Defining the Public Sphere in Eighteenth Century France: Variation on a theme by Habermas. In C. Calhoun, ed. Habermas and the Public Sphere. London: MIT Press.

Barata, A.M. 2009. Do secreto ao público: espaços de sociabilidade na Província de Minas Gerais (1822-1840). In J.M. Carvalho; L.M.B.P. Neves, eds. Repensando o Brasil do Oitocentos: cidadania, política e liberdade. Rio de Janeiro: Civilização Brasileira.

Barbosa, S.M. 2007. "Panfletos vendidos como canela": anotações em torno do debate político nos anos 1860. In J.M. Carvalho, ed. Nação e Cidadania no Império: novos horizontes. Rio de Janeiro: Civilização Brasileira.

Barboza Filho, R. 2003. Sentimento de democracia. Lua Nova, 59, pp. 5-49. 2008. As linguagens da democracia. Revista Brasileira de Ciências Sociais, 23(67), pp. 15-37.

Basile, M. 2000. Anarquistas, rusguentos e demagogos: os liberais exaltados e a formação da esfera pública na Corte imperial (1829-1834). Rio de Janeiro. Dissertação (Mestrado em História). Universidade Federal do Rio de Janeiro. 2007. Revolta e cidadania na Corte regencial. Tempo, 11(22), pp. 31-57.

Batalha, C. 1999. Sociedades de trabalhadores no Rio de Janeiro do século XIX: algumas reflexões em torno da formação da classe operária. Cadernos AEL, 6(10-11), pp. 41-68. 2000. O movimento operário na Primeira República. Rio de Janeiro: Jorge Zahar Editor. 2003. Formação da classe operária e projetos de identidade coletiva. In J. Ferreira; L. Neves, eds. O Brasil Republicano. V. 1. Rio de Janeiro: Civilização Brasileira. . 2004. Cultura associativa no Rio de Janeiro da Primeira República. In C. Batalha; F. Silva; A. Fortes, eds. Culturas de classe. Campinas: Editora da Unicamp.

Borges, C.M. 2005. Escravos e Libertos nas Irmandades do Rosário: devoção e solidariedade - Minas Gerais - séculos XVIII e XIX. Juiz de Fora: Editora da UFJF.

Boschi, R.R.; Diniz, E. 1991, O corporativismo na construção do espaço público. In R. Boschi, ed. Corporativismo e desigualdade: a construção do espaço público no Brasil. Rio de Janeiro: Rio Fundo Editora.

Calhoun, C. 1992. Introduction: Habermas and the public sphere. In , ed. Habermas and the Public Sphere. London: MIT Press. 2010. The Public Sphere in the Field of Power. Social Science History, 34(3), pp. 301-336.

2012. The Roots of Radicalism: Tradition, the public sphere, and early nineteenth century social movements. Chicago: The University of Chicago Press.

Candido, A. 1971. A formação da literatura brasileira: momentos decisivos. $4^{\mathrm{a}}$ Ed. São Paulo: Martins Fontes.

Cardoso, F.H. 1962. Capitalismo e escravidão no Brasil meridional: o negro na sociedade escravocrata do Rio Grande do Sul. São Paulo: Difel.

Carvalho, J.M. 1987. Os bestializados: o Rio de Janeiro e a República que não foi. São Paulo: Companhia das Letras. . 1998a. Entre a liberdade dos antigos e dos modernos: a República no Brasil. In J.M. Carvalho, ed. Pontos e Bordados: escritos de história e política. Belo Horizonte: Editora da UFMG.

. 1998b. Os bordados de João Candido. In J.M. Carvalho, ed. Pontos e Bordados: escritos de história e política. Belo Horizonte: Editora da UFMG.

. 2001. Os três povos da República. In: M.A. Rezende de Carvalho, ed. República no Catete. Rio de Janeiro: Museu da República.

2006. História intelectual no Brasil: a retórica como chave de leitura. Topoi, 1, pp. 123-152.

2007. As conferências radicais do Rio de Janeiro: novo espaço de debate. In J.M. Carvalho, ed. Nação e Cidadania no Império: novos horizontes. Rio de Janeiro: Civilização Brasileira.

Chalhoub, S. 1990. Visões da liberdade: uma história das últimas décadas da escravidão na corte. São Paulo: Companhia das Letras.

.2001. Trabalho, lar e botequim: o cotidiano dos trabalhadores no Rio de Janeiro da Belle Époque. São Paulo: Editora da Unicamp.

2006. The Politics of Silence: Race and citizenship in nineteenth-century Brazil. Slavery \& Abolition, 27(1), pp. 71-85.

2007. Solidariedade e liberdade: sociedades beneficentes de negros e negras do Rio de Janeiro na segunda metade do século XIX. In O.M.G. Cunha; F.S. Gomes, eds. Quase cidadão: histórias e antropologias da pós-emancipação no Brasil. Rio de Janeiro: Editora FGV.

Chalhoub, S.; Silva, F.T. 2009. Sujeitos no imaginário acadêmico: escravos e trabalhadores na historiografia brasileira desde os anos 1980. Cadernos Arquivo Edgard Leuenroth, 14(26), pp. 11-50.

Chauí, M. 1986. Conformismo e resistência: aspectos da cultura popular no Brasil. São Paulo: Editora Brasiliense.

Cohen, J.; Arato, A. 1992. Civil Society and Political Theory. London: MIT Press.

Connell, R. 2007. Southern Theory: The global dynamics of knowledge in social sciences.Cambridge (UK): Polity Press.

Coser, I. 2008. Visconde do Uruguai. Centralização e Federalismo no Brasil (1823-1866). Belo Horizonte/Rio de Janeiro: Editora UFMG/Iuperj.

Costa, E.V. 1982. Da senzala à colônia. São Paulo: Ciências Humanas. 
Costa, S. 2002. As cores de Ercília: esfera pública, democracia, configurações pós-nacionais. Belo Horizonte: Editora da UFMG.

Cunha, O.M.G.; Gomes, F.S. 2007. Introdução: Que cidadão? Retóricas da igualdade, cotidiano da diferença. In , eds. Quase cidadão: histórias e antropologias da pós-emancipação no Brasil. Rio de Janeiro: Editora FGV.

Dagnino, E. 2002. Sociedade civil, espaços públicos e a construção democrática no Brasil: limites e possibilidades. In ed. Sociedade civil e espaços públicos no Brasil. São Paulo: Paz e Terra.

Domingues, J.M. 2003. Imaginário social e esfera pública no Rio de Janeiro. In: Do Ocidente à modernidade: intelectuais e mudança social. Rio de Janeiro: Civilização Brasileira.

Eisenberg, J. 2003a. A democracia depois do liberalismo. Ensaios sobre ética, Direito e política. Rio de Janeiro: Relume Dumará. . 2003b. Internet, democracia e República. Dados, 46(3), pp. 491-511.

Eisenberg, J.; Cavalcante, B.; Starling, H. 2004. Decantando a República: um inventário histórico e político da canção popular moderna brasileira. 3 Vols. Rio de Janeiro: Nova Fronteira.

Elley, G. 1992. Nations, Publics and Political Cultures: Placing Habermas in the nineteenth century. In C. Calhoun, ed. Habermas and the Public Sphere. London: MIT Press.

Ferreira, J. 2001. O nome e a coisa: o populismo na política brasileira. In Rio de Janeiro: Civilização Brasileira, pp. 59-124.

Fraser, N. 1992. Rethinking the Public Sphere: A contribution to the critique of actually existing democracy. In C. Calhoun, ed. Habermas and the Public Sphere. London: MIT Press.

Freyre, G. 1990. Sobrados e Mucambos: decadência do patriciado rural e desenvolvimento urbano. $8^{\text {a }}$ ed. Rio de Janeiro: Record.

Gardiner, M.E. 2004. Wild Publics and Grotesque Symposiums: Habermas and Bakhtin on dialogue, everyday life and the public sphere. In N. Crossley; M. Roberts, eds. After Habermas: New perspectives on the public sphere. Oxford: Blackwell.

Gilroy, P. 2001. O Atlântico Negro. Modernidade e dupla consciência. Rio de Janeiro: Universidade Candido Mendes.

Gomes, A.C. 1988. A invenção do trabalhismo. Rio de Janeiro: Editora do Iuperj. 1999. Essa gente do Rio. Modernismo e Nacionalismo. Rio de Janeiro: Editora FGV.

Gomes, F.S.G. 2005. A hidra e os pântanos: mocambos, quilombos e comunidades de fugitivos no Brasil (séculos XVII-XIX). São Paulo: Editora da Unesp.

Gramsci, A. 2000. Cadernos do Cárcere. V. 3: Maquiavel. Notas sobre o Estado e a Política. Rio de Janeiro: Civilização Brasileira.

Guimarães, A.S. 2004. Intelectuais negros e formas de integração nacional. Estudos Avançados, 18(50), pp. 271-284.

Ginzburg, C. 1987. O queijo e os vermes: o cotidiano e as ideias de um moleiro perseguido pela Inquisição. São Paulo: Companhia das Letras.

Habermas, J. 1984. Mudança estrutural da esfera pública: investigações quanto a uma categoria da sociedade burguesa. Rio de Janeiro: Tempo Brasileiro. 1990. Soberania popular como procedimento.Novos Estudos, 26, pp. 100-113.

. 1992. Further Reflections on the Public Sphere. In C. Calhoun, ed. Habermas and the Public Sphere. London: MIT Press. 1997. Direito e democracia: entre faticidade e validade. Rio de Janeiro: Tempo Brasileiro. 2001. A constelação pós-nacional: ensaios políticos. São Paulo: Litera Mundi. 2002. O discurso filosófico da modernidade: doze lições. São Paulo: Martins Fontes.

. 2011. "The Political": The rational meaning of questionable inheritance of Political Theology. In E. Mendieta; J. Vanantwerpen, eds.The Power of Religion in the Public Sphere. New York: Columbia University Press. 2012. Teoria do agir comunicativo. São Paulo: Martins Fontes.

Hall, S. 2003. Notas sobre a desconstrução do “popular”. In L. Sovik, ed. Da diáspora: identidades e mediações culturais. Belo Horizonte: Editora da UFMG.

Hasenbalg, C. 1979. Discriminação e desigualdades raciais no Brasil. Belo Horizonte: Editora da UFMG.

Hoexter, M; Eisenstadt, S.; Levtzion, N., eds. 2002. The Public Sphere in Muslim Societies. New York: State University of New York Press.

Ianni, O. 1978. Escravidão e racismo. São Paulo: Hucitec.

Jesus, R.P. 2007. Associativismo no Brasil do Século XIX: repertório crítico dos registros de sociedades no Conselho de Estado (1860-1889). Locus, 13(1), pp. 63-96.

Laclau, E. 1990. New Reflections on Revolution Time. New York: Verso.

Lavalle, A.G. 2002. Jürgen Habermas e a virtualização da publicidade. Margem, 16, pp. 65-89.

Lessa, R. 1999. A invenção republicana. Campos Sales, as bases e a decadência da Primeira República Brasileira. $2^{\mathrm{a}}$ ed. Rio de Janeiro: Topbooks.

Lustosa, I. 2000. Insultos impressos: a guerra dos jornalistas na Independência (1821-1823). São Paulo: Companhia das Letras.

Machado, M.H.P.T. 1994. O plano e o pânico: movimentos sociais na década da abolição. Rio de Janeiro/ São Paulo: Editora da UFRJ/Edusp.

Maia, R.C.M. 2007a. Política deliberativa e tipologia de esfera pública. BIB, 63, pp. 91-116. 2007b. Redes cívicas e internet: efeitos democráticos do associativismo. Mídia e Democracia, 14, pp. 43-62. 
Montero, P. 2006. Religião, pluralismo e esfera pública. Novos Estudos, 74, pp. 47-66.

Morel, M. 2003. O período das regências (1831-1840). Rio de Janeiro: Jorge Zahar Editor.

2005. As transformações dos espaços públicos: imprensa, atores políticos e sociabilidade no Brasil imperial

(1820-1840). São Paulo: Hucitec.

Morse, R. 1988. O espelho de Próspero: cultura e idéias nas Américas. São Paulo: Companhia das Letras.

Nabuco, J. 2000. O abolicionismo. São Paulo: Publifolha.

Negt, O.; Kluge, A. 1993. Public Sphere and Experience: Toward an analysis of the bourgeois and proletarian public sphere.

Minneapolis: University of Minnesota Press.

Neves, L.M.B.P. 2003. Corcundas e constitucionais: a cultura política da Independência (1820-1822). Rio de Janeiro: Revan.

Ortiz, R. 1986. Cultura brasileira e identidade nacional. São Paulo: Brasiliense.

Ottmann, G. 2004. Habermas e a esfera pública no Brasil: considerações conceituais.Novos Estudos, 68, pp. 61-72.

Perlatto, F. 2011. Esfera pública e o Brasil. Entre a seletividade e a democratização. In: J. Trajano Sento-Sé, ed. Direitos humanos e segurança pública. Algumas premissas e abordagens. Rio de Janeiro: ISER.

2012. Habermas, a esfera pública e o Brasil. Revista Estudos Políticos, 4, pp. 78-94.

Pinto, C.R.J. 2003. Uma história do feminismo no Brasil. São Paulo: Fundação Perseu Abramo.

Priore, M.; Venâncio, R.P. 2004. Ancestrais: uma introdução à história da África Atlântica. Rio de Janeiro: Elsevier.

Reis, J.J. 1997. Identidade e diversidade étnicas nas Irmandades negras no tempo da escravidão. Tempo, 2(3), pp. 7-33.

Reis, J.J.; Silva, E. 1989. Negociação e conflito: a resistência negra no Brasil escravista. São Paulo: Companhia das Letras.

Rezende de Carvalho, M.A. 2007. Temas sobre a organização dos intelectuais no Brasil. Revista Brasileira de Ciências Sociais, 22(65), pp. 17-31.

Ribeiro, G. 2003. O desejo da liberdade e a participação política de homens livres pobres e de cor na Independência do Brasil. Cadernos do CEDES, 58, pp. 21-45.

2009. Cidadania e lutas por direitos na Primeira República: analisando processos da Justiça Federal e do Supremo Tribunal Federal. Tempo, 13(26), pp. 101-116.

Rios, F. 2012. O protesto negro no Brasil contemporáneo. Lua Nova, 85, pp. 41-47.

Rios, A.M.; Castro, H.M.M. 2007. Para além das senzalas: campesinato, política e trabalho rural no Rio de Janeiro pós-Abolição. In O.M.G. Cunha; F.S. Gomes, eds. Quase cidadão: histórias e antropologias da pós-emancipação no Brasil. Rio de Janeiro: Editora FGV.

Ryan, M.P. 1992. Gender and the Public Access: Women's politics in nineteenth century America. In C. Calhoun, ed. Habermas and the Public Sphere. London: MIT Press.

Sader, E. 1995. Quando novos personagens entraram em cena: experiências, falas e lutas dos trabalhadores da grande São Paulo (1970-1980). $2^{a}$ ed. São Paulo: Paz e Terra.

Salles, R. 1996. Nostalgia imperial: a formação da identidade nacional no Brasil no Segundo Reinado. Rio de Janeiro: Topbooks.

Santos, W.G. 1979. Cidadania e Justiça. Rio de Janeiro: Campus. 2006. Horizonte do desejo: instabilidade, fracasso coletivo e inércia social. Rio de Janeiro: Fundação Getúlio Vargas.

Schritzmeyer, A. 2004. Sortilégios de saberes: curandeiros e juízes nos tribunais brasileiros. São Paulo: Instituto Brasileiro de Ciências Criminais.

Schwarcz, L.M. 1998. As barbas do imperador. D. Pedro II, um monarca nos trópicos. São Paulo: Companhia das Letras. 2007. Dos males da dádiva: sobre as ambiguidades no processo da Abolição brasileira. In O.M.G. Cunha; F.S. Gomes, eds. Quase cidadão: histórias e antropologias da pós-emancipação no Brasil. Rio de Janeiro: Editora FGV.

Scott, J.C. 2003. Los dominados y el arte de la resistencia. Mexico: Txalaparta.

Sevcenko, N. 1993. A Revolta da Vacina: mentes insanas em corpos rebeldes. São Paulo: Editora Scipione. . 1998. O prelúdio republicano, astúcias da ordem e ilusões do progresso. In História da vida privada no Brasil: da Belle Époque à era do rádio. V. 3. São Paulo: Companhia das Letras.

Silva, E. 1988. As queixas do povo. Rio de Janeiro: Editora Paz e Terra.

Silva, J. 2003. A União dos Homens de Cor: aspectos do movimento negro dos anos 40 e 50. Estudos Afro-Asiáticos, 25(2), pp. 215-236.

Soares, M.C.; Salles, R.H. 2005. Episódios de história afro-brasileira. Rio de Janeiro: DP\&A/Fase.

Souza, J. 2000. A modernização seletiva: uma reinterpretação do dilema brasileiro. Brasília: Editora da UnB.

Souza, M.M. 2002. Reis negros no Brasil escravista. História da festa de coroação de rei congo. Belo Horizonte: Editora da UFMG.

Spivak, G. 1988. Can the Subaltern Speak? In C. Nelson; L. Grossberg, eds. Marxism and the Interpretation of Culture. Urbana: University of Illinois Press.

Squires, C. 2002. Rethinking the Black Public Sphere: An alternative vocabulary for multiple publics. Communication Theory, 12(4), pp. 446-468.

Tavolaro, S. 2005. Existe uma modernidade brasileira? Reflexões em torno de um dilema sociológico brasileiro. Revista Brasileira de Ciências Sociais, 20(59), pp. 5-22.

Taylor, C. 2000. Propósitos entrelaçados. O debate liberal comunitário. In Argumentos filosóficos. São Paulo: Editora Loyola.

Viscardi, C.; Jesus, R.P. 2007. A experiência mutualista e a formação da classe trabalhadora no Brasil. In J. Ferreira; D.A. Reis, eds. As esquerdas no Brasil: a formação das tradições (1889-1945). Rio de Janeiro: Civilização Brasileira. 
Walzer, M. 1990. The Communitarian Critique of Liberalism. Political Theory, 18(1), pp. 6-23.

Wampler, B.; Avritzer, L. 2004. Públicos participativos: sociedade civil e novas instituições no Brasil democrático. In V.S. Coelho; M. Nobre, eds. Participação e deliberação: teoria democrática e experiências institucionais no Brasil contemporâneo. São Paulo: Editora 34.

Warner, M. 2002. Publics and Counterpublics. New York: Zone Books.

Weffort, F.C. 1973. Origens do sindicalismo populista no Brasil: a conjuntura do pós-guerra.Novos Estudos, 4, pp. 67-105.

Werneck Vianna, L. 2004. A revolução passiva: iberismo e americanismo no Brasil. $2^{a}$ ed. Rio de Janeiro: Revan.

Werneck Vianna, L.; Rezende de Carvalho, M.A. 2000. República e a civilização brasileira. In N. Bignotto, ed. Pensar a República. Belo Horizonte: Editora da UFMG.

2004. Experiência brasileira e democracia. In S. Cardoso, ed. Retorno ao Republicanismo. Belo Horizonte: Editora da UFMG.

Williams, R. 1979. Marxismo e literatura. Rio de Janeiro: Jorge Zahar Editor.

Zaret, D. 1992. Religion, Science, and Printing in the Public Spheres in Seventeenth-Century England. In C. Calhoun, ed. Habermas and the Public Sphere. London: MIT Press.

\begin{abstract}
This article aims to analyze the process of construction of the public sphere in Brazil. It advances the hypothesis that, since the nineteenth century, a selective public sphere and subaltern public spheres have been in place in Brazil. To support this argument, the article begins with a discussion of the international literature devoted to the reflection on the concept of public sphere - especially with the formulations made by and from Jürgen Habermas - with the aim of exploring the transformations that this category has undergone over the years, with special emphasis on the concept of "subaltern counterpublics" proposed by Nancy Fraser. Furthermore, based on historiographical studies that have been carried out in the last decades focusing on Brazilian society of the nineteenth and twentieth centuries, the article advances a theoretical formulation of the process of construction of the public sphere in Brazil. Besides questioning the theories that support the nonexistence of a public sphere in the country, or that it only came into existence in the late twentieth century, we intend, in this article, to highlight not only to the need for a more accurate historical analysis for understanding the "selective public sphere" and the "subaltern public spheres" but an analytic movement towards realizing other forms of legitimate associativism that do not reproduce the organizational paradigm of the European or North American world. We hope that this paper can contribute both to a better comprehension of the historical process of construction of the public sphere in Brazil, as well as to a better understanding of the dynamics of organization and mobilization of "subaltern public spheres", drawing attention to its potential for the further democratization of the country
\end{abstract}

KEYWORDS: public sphere; Habermas; subalterns; modernity; democracy.

License information: This is an open-access article distributed under the terms of the Creative Commons Attribution License, which permits unrestricted use, distribution, and reproduction in any medium, provided the original work is properly cited. 